\title{
Beryllium Stress-Induced Modifications in Antioxidant Machinery and Plant Ultrastructure in the Seedlings of Black and Yellow Seeded Oilseed Rape
}

\author{
Skhawat Ali, ${ }^{1}$ Rong Jin, ${ }^{2}$ Rafaqat A. Gill ${ }^{1},{ }^{3}$ Theodore M. Mwamba, ${ }^{1}$ Na Zhang, \\ Zaid ul Hassan, ${ }^{1}$ Faisal Islam, ${ }^{1}$ Shafaqat Ali $\mathbb{D}^{4},{ }^{4}$ and Weijun Zhou ${ }^{1}{ }^{1}$ \\ ${ }^{1}$ Institute of Crop Science and Zhejiang Key Laboratory of Crop Germplasm, Zhejiang University, Hangzhou 310058, China \\ ${ }^{2}$ Agricultural Experiment Station, Zhejiang University, Hangzhou 310058, China \\ ${ }^{3}$ Oil Crops Research Institute, Chinese Academy of Agricultural Sciences, Wuhan 430062, China \\ ${ }^{4}$ Department of Environmental Sciences and Engineering, Government College University, Faisalabad 38000, Pakistan \\ Correspondence should be addressed to Weijun Zhou; wjzhou@zju.edu.cn
}

Received 11 October 2017; Revised 9 January 2018; Accepted 31 January 2018; Published 21 March 2018

Academic Editor: Pengjun Shi

Copyright (C) 2018 Skhawat Ali et al. This is an open access article distributed under the Creative Commons Attribution License, which permits unrestricted use, distribution, and reproduction in any medium, provided the original work is properly cited.

\begin{abstract}
Beryllium $(\mathrm{Be})$ could be a threatening heavy metal pollutant in the agroecosystem that may severely affect the performance of crops. The present study was conducted to evaluate the toxic effects of $\mathrm{Be}(0,100,200$, and $400 \mu \mathrm{M})$ on physiological, ultrastructure, and biochemical attributes in hydroponically grown six-day-old seedlings of two cultivars of Brassica napus L., one tolerant (ZS 758, black seeded) and one sensitive (Zheda 622, yellow seeded). Higher Be concentrations reduced the plant growth, biomass production, chlorophyll contents, and the total soluble protein contents. A significant accumulation of $\mathrm{ROS}\left(\mathrm{H}_{2} \mathrm{O}_{2}, \mathrm{OH}^{-}\right)$and MDA contents was observed in a dose-dependent manner. Antioxidant enzymatic activities including SOD, POD, GR, APX, and GSH (except CAT) were enhanced with the increase in Be concentrations in both cultivars. Relative transcript gene expression of above-mentioned antioxidant enzymes further confirmed the alterations induced by Be as depicted from higher involvement in the least susceptible cultivar ZS 758 as compared to Zheda 622. The electron microscopic study showed that higher level of Be (400 $\mu \mathrm{M})$ greatly damaged the leaf mesophyll and root tip cells. More damage was observed in cultivar Zheda 622 as compared to ZS 758 . The damage in leaf mesophyll cells was highlighted as the disruption in cell wall, immature nucleus, damaged mitochondria, and chloroplast structures. In root tip cells, disruption in Golgi bodies and damage in cell wall were clearly noticed. As a whole, the present study confirmed that more inhibitory effects were recorded in yellow seeded Zheda 622 as compared to black seeded ZS 758 cultivar, which is regarded as more sensitive cultivar.
\end{abstract}

\section{Introduction}

Oilseed rape (Brassica napus L., AACC genome) has developed through allopolyploids between two diploid parents, Brassica rapa (AA genome) and B. oleracea (CC genome) [1]. $B$. napus belongs to the family Brassicaceae which has been extensively used for the phytoextraction [2]. Brassica species have become the second largest oil producing crop since the last decade [3]. These species have greater potential to grow well under heavy metal (HM) contaminated soils because of their higher metal tolerance ability [4]. Due to these unique properties, B. napus has gained the attention of researchers in recent years [5].

HM toxic effects in the surrounding environment impose severe threats to agricultural crop production and quality by reducing the plant growth and yield $[6,7]$. The excessive HM concentrations reduce the seed germination [8] and photosynthesis and cause nutrient balance, root damage, and ultimately plant death $[6,9]$. The oxidative stress induced by HMs increases the production of reactive oxygen species (ROS) [8]. To cope with these ROS, plants have developed antioxidant scavenging system in the form of total superoxide 
dismutase (SOD), peroxidase (POD), catalase (CAT), ascorbate peroxidase (APX), glutathione reductase (GR), and the contents of reduced glutathione (GSH), oxidized glutathione (GSSG), and total glutathione (GSH + GSSG) [10]. Furthermore, HM stresses significantly alter the cellular protein functions and thylakoid membrane structures, which are directly associated with plant photosystem [11-13]. In addition, HMs impair lipid composition of cell membrane $[14,15]$ and higher accumulation in agricultural soil system results in health hazards due to their direct entry into food chain [16].

Beryllium (Be) is the element of group IIA in periodic table with an average concentration of $2.8-5 \mathrm{mg} / \mathrm{kg}$ on the earth's crust [17]. It has gained worldwide economic attention due to its extensive use in nuclear weapons, reactors, Xray machines, electronic industries, and aircraft structures [18]. However, its entry into the environment has become alarming for the sustainability of the ecosystem [19]. Major entry sources of Be into our ecosystem are fossil fuel burning, industrial discharge, and atmospheric emission [16]. Be is readily taken up by plants and accumulates into their edible parts [20].

It has been found that higher levels of Be appreciably declined the growth of soybean young seedlings [21] and yield reduction by $50 \%$ in cabbage [22]. In addition, it reduces the seed germination, root length, and dry weight in various plants [23]. Recently, Agrawal et al. [24] found that Be significantly enhanced the lipid peroxidation rate and reduced glutathione level and antioxidant enzyme activities. Inorganic salts of $\mathrm{Be}$, such as $\mathrm{BeCl}_{2}$, are generally more toxic to plants, mainly because of their high solubility. Moreover, Encina and Becerra [25] proposed that a particular level of membrane-associated $\mathrm{Ca}$ is essential for the fusion of Golgi vesicles in the cell plate. The presence of Be might displace the Ca from its binding sites, which can hinder the cell formation.

Brassica species have potential to tolerate against HM stresses. Therefore, it is imperative to evaluate the responses and mechanism of these species against Be stress. It has been discussed previously that Be declined the plant growth and yield by inhibiting morphology, physiology, and biochemical processes $[19,26]$. Since limited data is available regarding morphological and physiobiochemical responses of plants to Be-toxicity in Brassica species, the present study was carried out to understand the growth, photosynthesis, oxidative stress, and antioxidant and ultrastructural modifications induced by Be-toxicity in response to two B. napus cultivars, that is, ZS 758 (black seeded, tolerant) and Zheda 622 (yellow seeded, sensitive).

\section{Materials and Methods}

Two potential cultivars (ZS 758, black seeded; Zheda 622, yellow seeded) of oilseed rape (B. napus) used in the present study were selected on the basis of our previous study [6] in which these cultivars showed significant differences in their metal tolerance ability. Good quality and mature seeds were obtained from the College of Agriculture and Biotechnology, Zhejiang University. At first, seeds were treated with $70 \%$ (v/v) ethanol for $3 \mathrm{~min}$, transferred into $0.1 \%(\mathrm{~m} / \mathrm{v}) \mathrm{HgCl}_{2}$, and then rinsed with deionized water thoroughly. A total of 40 seeds were positioned in every Petri dish on wet filter paper for overnight. After germination, 25 seedlings were randomly chosen for every treatment and then transferred to plastic Petri dishes $\left(12 \mathrm{~cm}^{2}\right)$ with two pieces of filter papers lying on sponge. To which, $6 \mathrm{~mL}$ of beryllium $(\mathrm{Be})$ solutions $(0,100,200$, and $400 \mu \mathrm{M})$ were added. After $24 \mathrm{~h}$, the excessive solution was discarded and seedlings were treated with half-strength Hoagland's solution. Beryllium sulphate $\left(\mathrm{BeSO}_{4}\right)$ salt was used to maintain different $\mathrm{Be}$ concentrations. Four replications per treatment were taken in full-strength Hoagland's solution. Seedlings were allowed to grow in controlled conditions with day/night temperatures of $25 / 20^{\circ} \mathrm{C}$, a $16-\mathrm{h}$ photoperiod, an irradiance of $300 \mu \mathrm{mol} \mathrm{m} \mathrm{s}^{-1}$, and a relative humidity of $60-70 \%$. After 8 days of treatment, seedlings were harvested and separated into shoots and roots for the determinations of morphological, ultrastructural, and biochemical characteristics.

Plant growth characteristics regarding the shoot and root lengths were measured. Fresh and dry biomasses of plant parts, that is, leaf, stem, and root, were measured according to Zhang et al. [27]. The method employed by Porra et al. [28] was followed to analyze the chlorophyll (Chl a, b) and carotenoids (Car) contents.

Lipid peroxidation in B. napus seedlings was analyzed regarding malondialdehyde (MDA) by following the procedure of Zhou and Leul [29]. Fresh samples ( $0.5 \mathrm{~g}$ ) of leaves and roots were extracted in $8 \mathrm{~mL}$ of $0.25 \%$ thiobarbituric acid (TBA) in 10\% trichloroacetic acid (TCA). Then the extract was heated at $95^{\circ} \mathrm{C}$ for $30 \mathrm{~min}$ and then cooled on ice. After this, the samples were centrifuged at 5,000 $\times \mathrm{g}$ for $10 \mathrm{~min}$, and absorbance was checked at $532 \mathrm{~nm}$. The level of MDA was expressed as $\mathrm{mmolg}^{-1}$ protein by using extinction coefficient $\left(155 \mathrm{mM} \mathrm{cm}^{-1}\right)$. Hydrogen peroxide $\left(\mathrm{H}_{2} \mathrm{O}_{2}\right)$ contents were measured according to Gong et al. [30]. The samples $(0.5 \mathrm{~g})$ were treated with $0.1 \%(\mathrm{w} / \mathrm{v})$ trichloroacetic acid (TCA) $(5 \mathrm{~mL})$ in ice bath. The homogenized samples were centrifuged for $15 \mathrm{~min}$ at 12,000 $\times \mathrm{g}$ (Eppendorf AG, model 2231, Hamburg, Germany). Then, supernatant $(1.5 \mathrm{~mL})$ was mixed with $0.5 \mathrm{~mL}$ of $10 \mathrm{mM}$ potassium phosphate buffer $(\mathrm{pH} 7.0)$ and $1 \mathrm{M} \mathrm{KI}(1 \mathrm{~mL})$. The absorbance was taken at $390 \mathrm{~nm}$, and $\mathrm{H}_{2} \mathrm{O}_{2}$ contents were calculated by using a standard curve [31]. For the quantification of hydroxyl radicals $\left(\mathrm{OH}^{-}\right), 0.5 \mathrm{~g}$ fresh samples were treated with $3 \mathrm{~mL}$ of $10 \mathrm{mM} \mathrm{Na}$-phosphate buffer (pH 7.4) consisting of 15 mM 2-deoxy-D-ribose (SRL, Mumbai) at $37^{\circ} \mathrm{C}$ for $2 \mathrm{~h} \mathrm{[32].} \mathrm{After} \mathrm{this,} \mathrm{an} \mathrm{aliquot} \mathrm{of} 0.7 \mathrm{~mL}$ of the above-homogenized samples were added to a reaction mixture containing $3 \mathrm{~mL}$ of $0.5 \%(\mathrm{w} / \mathrm{v})$ thiobarbituric acid (TBA), $1 \%$ stock solution made in $5 \mathrm{mM} \mathrm{NaOH}$, and $1 \mathrm{~mL}$ glacial acetic acid, then heated at $100^{\circ} \mathrm{C}$ in a water bath for $30 \mathrm{~min}$, and cooled down to $41^{\circ} \mathrm{C}$ for $10 \mathrm{~min}$. Absorbance was checked at $550 \mathrm{~nm}$ by using a spectrophotometer.

Law et al. [33] method was followed to estimate the reduced glutathione (GSH) and oxidized glutathione (GSSG) in plant samples. $0.5 \mathrm{~g}$ samples were treated with $5 \mathrm{~mL}$ of $10 \%(\mathrm{w} / \mathrm{v})$ trichloroacetic acid (TCA) and then centrifuged at $15,000 \times \mathrm{g}$ for $15 \mathrm{~min}$. For the estimation of GSH contents, the supernatant of $0.150 \mathrm{~mL}$ was mixed with $100 \mu \mathrm{L}$ of $6 \mathrm{mM}$ 
dithionitrobenzoate (DTNB), $50 \mu \mathrm{L}$ of glutathione reductase $\left(10\right.$ units $\mathrm{mL}^{-1}$ ), and $0.7 \mathrm{~mL}$ of $0.3 \mathrm{mM} \mathrm{NADPH}$. To measure GSSG, the supernatant of $0.120 \mathrm{~mL}$ was combined with $0.010 \mathrm{~mL}$ of 2 -vinylpyridine followed by the addition of $0.020 \mathrm{~mL}$ of $50 \%(\mathrm{v} / \mathrm{v})$ triethanolamine. Then, the solution was well-mixed with vortex for the $30 \mathrm{~s}$ and incubated at $25^{\circ} \mathrm{C}$ for $25 \mathrm{~min}$. At the end, reduced glutathione contents were determined by subtracting GSSG from the total glutathione content.

Antioxidant enzyme activities were measured according to Zhang [34] with some modifications. Fresh samples ( $0.5 \mathrm{~g})$ were ground in $8 \mathrm{~mL}$ of $50 \mathrm{mM}$ potassium phosphate buffer $(\mathrm{pH}$ 7.8) under cold conditions, then homogenized, and centrifuged at $10,000 \mathrm{~g}$ at $4^{\circ} \mathrm{C}$ for $20 \mathrm{~min}$. After this, the supernatant was taken for the enzymatic assays [35]. Total superoxide dismutase (SOD) activity was assessed by following the inhibition of photochemical reduction of nitroblue tetrazolium (NBT) [27]. Reaction mixture was comprised of $50 \mathrm{mM}$ potassium phosphate buffer ( $\mathrm{pH} 7.8), 0.075 \mathrm{~mL}$ NBT, $0.002 \mathrm{~mL}$ riboflavin, $13 \mathrm{mM}$ methionine, $0.1 \mathrm{mM}$ EDTA, and $0.100 \mathrm{~mL}$ of enzyme extract in a $3 \mathrm{~mL}$ volume. One unit of SOD activity was measured as the amount of enzyme required to cause $50 \%$ inhibition of NBT reduction measured at $560 \mathrm{~nm}$. Peroxidase (POD) activity was assayed by following Leul and Zhou [35] with some modifications. The reactant mixture contained $50 \mathrm{mM}$ potassium phosphate buffer $(\mathrm{pH}$ 7.0), $0.4 \% \mathrm{H}_{2} \mathrm{O}_{2}, 1 \%$ guaiacol, and $0.1 \mathrm{~mL}$ enzyme extract. Variation due to guaiacol was measured at $470 \mathrm{~nm}$. Catalase (CAT) activity was assayed with the use of $\mathrm{H}_{2} \mathrm{O}_{2}$ (extinction coefficient $39.4 \mathrm{~m} \mathrm{~cm}^{-1}$ ) for $1 \mathrm{~min}$ at $240 \mathrm{~nm}$ in $3 \mathrm{~mL}$ reaction mixture containing $50 \mathrm{mM}$ potassium phosphate buffer ( $\mathrm{pH}$ 7.0), $10 \mathrm{mM} \mathrm{H}_{2} \mathrm{O}_{2}, 2 \mathrm{mM}$ EDTA-Na2, and $0.1 \mathrm{~mL}$ enzyme extract [36]. The ascorbate peroxide (APX) activity was estimated in a reaction solution comprised of $100 \mathrm{mM}$ phosphate (pH 7), $0.06 \mathrm{mM} \mathrm{H}_{2} \mathrm{O}_{2}, 0.3 \mathrm{mM}$ ascorbic acid (AsA), $0.1 \mathrm{mM}$ EDTA- $\mathrm{Na}_{2}$, and $0.1 \mathrm{~mL}$ enzyme extract [37]. The absorption was measured at $290 \mathrm{~nm}$ after the addition of $\mathrm{H}_{2} \mathrm{O}_{2}$. Glutathione reductase (GR) activity was determined according to Jiang and Zhang [38] with the oxidation of NADPH for $1 \mathrm{~min}$ at $340 \mathrm{~nm}$ (extinction coefficient $6.2 \mathrm{mM} \mathrm{cm}^{-1}$ ). The reaction mixture was comprised of $50 \mathrm{mM}$ potassium phosphate buffer ( $\mathrm{pH}$ 7.0), $0.15 \mathrm{mM}$ NADPH, $2 \mathrm{mM}$ EDTA$\mathrm{Na}_{2}, 0.5 \mathrm{mM}$ GSSG, and $0.1 \mathrm{~mL}$ enzyme extract in a $1 \mathrm{~mL}$ volume. Total soluble protein (TSP) content was measured by following the method of Bradford [39]. Bovine serum albumin was used as a standard.

Total RNA was extracted from $\sim 100 \mathrm{mg}$ frozen leaf and root tissues using manual (Trizol) method. To remove the genomic DNA and cDNA synthesis, prime Script ${ }^{\mathrm{TM}} \mathrm{RT}$ reagent kit (Takara, Co. Ltd., Japan) with gDNA (genomic DNA) eraser was used. cDNA samples from different treatments were assayed by quantitative real-time PCR (qRTPCR) in the iCycleriQTM real-time detection system (BioRad, Hercules, CA, USA) by using SYBRR Premix Ex Taq II (Takara, Co. Ltd., Japan). The software given with the PCR system was used to calculate the threshold cycle values [40]. Table S1 summarizes the specific primers used for each gene.
For ultrastructural analysis of leaf, fragments without veins (about $1 \mathrm{~mm}^{2}$ ) and root tips (about 2-3 mm) were fixed in $2.5 \%$ glutaraldehyde $(\mathrm{v} / \mathrm{v})$ in $0.1 \mathrm{M}$ potassium phosphate buffer (PBS, pH 7.4) overnight and washed three times with the same PBS. Later, samples were postfixed in $1 \% \mathrm{OsO}_{4}$ [osmium (VIII) oxide] for $1 \mathrm{~h}$ and then washed three times in $0.1 \mathrm{M}$ PBS ( $\mathrm{pH}$ 7.4) with 10-min intervals between each washing. After 15-20-min, the samples were dehydrated in a graded series of ethanol $(50 \%, 60 \%, 70 \%, 80 \%, 90 \%, 95 \%$, and $100 \%$ ) and then used the absolute acetone for $20 \mathrm{~min}$. The samples were infiltrated and embedded in Spurr's resin overnight. After heating at $70^{\circ} \mathrm{C}$ for $9 \mathrm{~h}$, ultrathin sections $(80 \mathrm{~nm})$ of specimens were prepared and mounted on copper grids for the observation in transmission electron microscope (JEOL TEM-1230EX, Tokyo, Japan) at an accelerating voltage of $60.0 \mathrm{kV}$.

Analysis of variance (ANOVA) was carried out by using statistical analysis package SPSS, version 16.0 (SPSS, Chicago, IL, USA); differences were considered significant at $P<$ 0.05 . Data are the means \pm standard deviation (SD) of three independent replicates. Significant means were compared by following Duncan's multiple range test.

\section{Results}

Plant growth characteristics regarding the shoot height, root elongation, and biomass production were severely affected by Be stress in a dose-dependent manner in both cultivars (Table 1). Be-induced deleterious effects were also evident even at the lowest dose $(100 \mu \mathrm{M})$, except for shoot height and stem fresh weight in ZS 758, as well as root fresh weight in both ZS 758 and Zheda 622. In recent studies, we reported a differing level of metal tolerance ability of cultivars ZS 758 and Zheda 622 under $\mathrm{Cr}$ [6], $\mathrm{Cu}$, and $\mathrm{Cd}$ [41] stress. However, in this study, a relatively less difference was observed in the sensitivity and tolerance ability of these cultivars against $\mathrm{Be}$ stress. At the exposure of different Be concentrations (100, 200 , and $400 \mu \mathrm{M}$ ), no big genotypic difference was observed among all growth parameters except for dry leaf weight (Table 1). The detrimental effects of Be were evidenced on chlorophyll and carotenoids contents in both cultivars of B. napus leaves (Table 2). Less obvious deleterious effects were noticed in chlorophyll contents at the lowest level of Be exposure $(100 \mu \mathrm{M})$. The chlorophyll contents (Chl a, b) were decreased significantly with the increase in Be levels in both cultivars. A clear genotypic difference was observed at 200 and $400 \mu \mathrm{M}$ Be levels, contrary to the morphological observations. However, highest level of Be $(400 \mu \mathrm{M})$ was more detrimental to chlorophyll contents irrespective of the cultivars used. The levels of total soluble protein in the leaves of $B$. napus seedlings were gradually reduced with the increase in Be concentrations. Nonsignificant genotypic differences were noted at lower Be concentration $(100 \mu \mathrm{M})$, in comparison with 200 and $400 \mu \mathrm{M}$ (Table 2). Overall, higher protein levels were prominent in ZS 758 as compared to Zheda 622.

The accumulation of ROS and the subsequent oxidation of lipids in terms of MDA contents are the reliable indication of cellular damage occurred in plants. The exposure of $B$. 


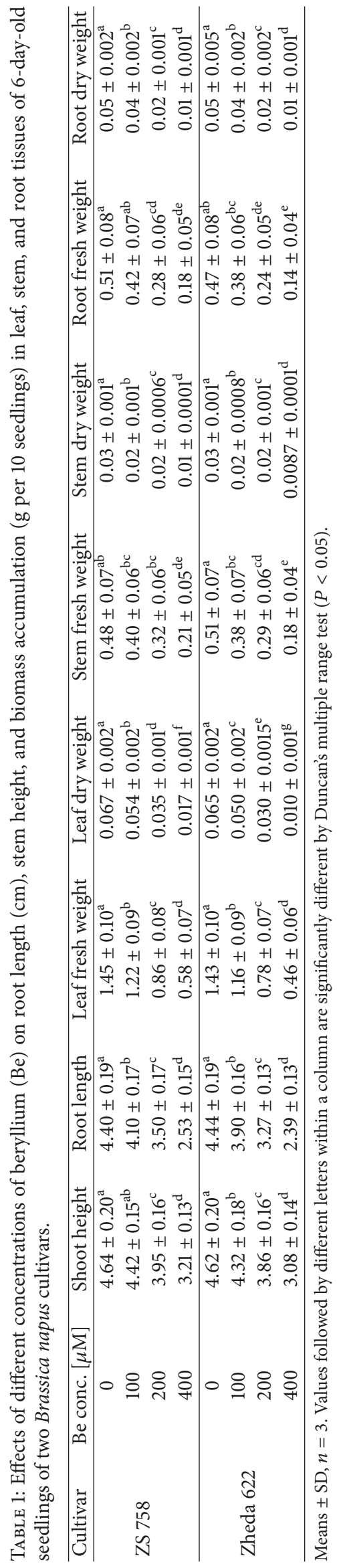


TABLE 2: Effects of different concentrations of beryllium (Be) on chlorophyll contents $\left[\mathrm{mg} \mathrm{g}^{-1}\right.$ (f.m.)] and leaf total soluble proteins (TSP) $\left[\mathrm{mg} \mathrm{g}^{-1}\right.$ (f.m.)] in cotyledons of 6-day-old seedlings of two Brassica napus cultivars.

\begin{tabular}{lccccc}
\hline Cultivar & Be conc. $[\mu \mathrm{M}]$ & Chlorophyll a & Chlorophyll b & Carotenoid & TSP \\
\hline \multirow{4}{*}{ ZS 758 } & 0 & $35.78 \pm 2.37^{\mathrm{a}}$ & $65.84 \pm 2.96^{\mathrm{b}}$ & $47.70 \pm 2.65^{\mathrm{a}}$ & $2.44 \pm 0.03^{\mathrm{a}}$ \\
& 100 & $31.65 \pm 2.27^{\mathrm{b}}$ & $55.72 \pm 2.50^{\mathrm{c}}$ & $43.44 \pm 2.77^{\mathrm{b}}$ & $2.28 \pm 0.02^{\mathrm{c}}$ \\
& 200 & $23.64 \pm 1.36^{\mathrm{c}}$ & $33.43 \pm 1.66^{\mathrm{d}}$ & $31.49 \pm 2.42^{\mathrm{c}}$ & $2.02 \pm 0.03^{\mathrm{e}}$ \\
& 400 & $10.58 \pm 1.07^{\mathrm{e}}$ & $19.57 \pm 0.83^{\mathrm{f}}$ & $19.73 \pm 1.90^{\mathrm{d}}$ & $1.97 \pm 0.01^{\mathrm{f}}$ \\
Zheda 622 & 0 & $37.5 \pm 1.73^{\mathrm{a}}$ & $69.82 \pm 2.81^{\mathrm{a}}$ & $51.74 \pm 2.81^{\mathrm{a}}$ & $2.39 \pm 0.03^{\mathrm{b}}$ \\
& 100 & $29.66 \pm 1.84^{\mathrm{b}}$ & $53.07 \pm 2.81^{\mathrm{c}}$ & $41.19 \pm 2.65^{\mathrm{b}}$ & $2.25 \pm 0.02^{\mathrm{c}}$ \\
& 200 & $18.30 \pm 1.17^{\mathrm{d}}$ & $28.46 \pm 1.23^{\mathrm{e}}$ & $28.76 \pm 2.15^{\mathrm{c}}$ & $2.07 \pm 0.02^{\mathrm{d}}$ \\
\hline
\end{tabular}

Means $\pm \mathrm{SD}, n=3$. Values followed by different letters within a column are significantly different by Duncan's multiple range test $(P<0.05)$.

TABLE 3: Effects of different concentrations of beryllium (Be) on hydroxyl ion $\left({ }^{-} \mathrm{OH}\right)\left[\mu \mathrm{mol} \mathrm{g}^{-1}\right.$ (f.m.) $]$, hydrogen peroxide $\left(\mathrm{H}_{2} \mathrm{O}_{2}\right)\left[\mu \mathrm{mol} \mathrm{g}^{-1}\right.$ (f.m.)], and malondialdehyde (MDA) [nmol mg ${ }^{-1}$ (protein)] contents in leaves and roots of 6-day-old seedlings of two Brassica napus cultivars.

\begin{tabular}{|c|c|c|c|c|c|c|c|}
\hline \multirow{2}{*}{ Cultivar } & \multirow{2}{*}{ Be conc. $[\mu \mathrm{M}]$} & \multicolumn{2}{|c|}{$\mathrm{OH}^{-}$content } & \multicolumn{2}{|c|}{$\mathrm{H}_{2} \mathrm{O}_{2}$ content } & \multicolumn{2}{|c|}{ MDA content } \\
\hline & & Leaf & Root & Leaf & Root & Leaf & Root \\
\hline \multirow{4}{*}{ ZS 758} & 0 & $0.14 \pm 0.002^{g}$ & $0.103 \pm 0.001^{\mathrm{c}}$ & $1.65 \pm 0.02^{g}$ & $1.33 \pm 0.02^{\mathrm{g}}$ & $8.49 \pm 1.24^{\mathrm{d}}$ & $7.58 \pm 1.20^{\mathrm{d}}$ \\
\hline & 100 & $0.15 \pm 0.003^{\mathrm{f}}$ & $0.105 \pm 0.001^{c}$ & $1.78 \pm 0.02^{\mathrm{f}}$ & $1.43 \pm 0.02^{f}$ & $10.61 \pm 1.17^{\mathrm{cd}}$ & $9.24 \pm 1.28^{\mathrm{d}}$ \\
\hline & 200 & $0.18 \pm 0.003^{\mathrm{d}}$ & $0.113 \pm 0.015^{\mathrm{c}}$ & $1.99 \pm 0.02^{\mathrm{d}}$ & $1.62 \pm 0.02^{\mathrm{d}}$ & $14.59 \pm 2.13^{\mathrm{b}}$ & $13.43 \pm 2.13^{c}$ \\
\hline & 400 & $0.22 \pm 0.004^{\mathrm{b}}$ & $0.193 \pm 0.015^{\mathrm{b}}$ & $2.33 \pm 0.03^{\mathrm{b}}$ & $1.82 \pm 0.03^{\mathrm{b}}$ & $21.69 \pm 2.95^{\mathrm{a}}$ & $17.59 \pm 1.73^{\mathrm{b}}$ \\
\hline \multirow{4}{*}{ Zheda 622} & 0 & $0.14 \pm 0.002^{g}$ & $0.099 \pm 0.001^{c}$ & $1.68 \pm 0.02^{\mathrm{g}}$ & $1.29 \pm 0.02^{\mathrm{g}}$ & $7.80 \pm 0.98^{\mathrm{d}}$ & $7.62 \pm 1.40^{\mathrm{d}}$ \\
\hline & 100 & $0.17 \pm 0.004^{\mathrm{e}}$ & $0.104 \pm 0.002^{c}$ & $1.85 \pm 0.02^{\mathrm{e}}$ & $1.49 \pm 0.02^{\mathrm{e}}$ & $9.13 \pm 1.80^{\mathrm{d}}$ & $12.45 \pm 1.00^{\mathrm{c}}$ \\
\hline & 200 & $0.21 \pm 0.003^{c}$ & $0.114 \pm 0.002^{c}$ & $2.09 \pm 0.02^{c}$ & $1.69 \pm 0.04^{c}$ & $13.43 \pm 1.92^{b c}$ & $16.34 \pm 1.89^{b}$ \\
\hline & 400 & $0.25 \pm 0.004^{\mathrm{a}}$ & $0.260 \pm 0.02^{\mathrm{ca}}$ & $2.56 \pm 0.03^{\mathrm{a}}$ & $1.98 \pm 0.03^{\mathrm{a}}$ & $19.77 \pm 1.90^{\mathrm{a}}$ & $24.51 \pm 1.85^{\mathrm{a}}$ \\
\hline
\end{tabular}

Means \pm SD, $n=3$. Values followed by different letters within a column are significantly different by Duncan's multiple range test $(P<0.05)$.

napus seedlings to elevated levels of Be caused a marked induction of $\operatorname{ROS}\left(\mathrm{H}_{2} \mathrm{O}_{2}\right.$ and $\left.\mathrm{OH}^{-}\right)$and $\mathrm{MDA}$ contents in the root and leaf tissues of both cultivars (Table 3). At $100 \mu \mathrm{M}$ Be level, sufficient contents of ROS were induced in both root and leaf tissues. A reduction in the accumulation of MDA contents was prominent at 200 and $400 \mu \mathrm{M}$. The accumulation of $\mathrm{OH}^{-}$contents was insignificant at $100 \mu \mathrm{M} \mathrm{Be}$ in leaves. In roots, a significant difference was obvious at the highest Be dose $(400 \mu \mathrm{M})$. Similar trends in the accumulation of ROS and MDA contents were noted in both cultivars. It was apparent that Zheda 622 was more susceptible to Be stress as compared to ZS 758, which is evident from the induction of $\mathrm{H}_{2} \mathrm{O}_{2}, \mathrm{OH}^{-}$, and MDA contents.

Plants develop nonenzymatic antioxidant system against HM stress in the form of glutathione (GSH), which is the primary detoxifying system [42]. The alterations in the GSH and GSSG contents were observed in the leaves and roots of B. napus cultivars under various levels of Be (Table S2). A marked increase in GSH and GSSG contents was observed in both $B$. napus cultivars in a dose-dependent manner. At 200 and $400 \mu \mathrm{M}$ Be levels, higher GSH and GSSG contents were observed as compared with the control and $100 \mu \mathrm{M}$. At $400 \mu \mathrm{M}$ Be level, maximum increase in both GSH and GSSG contents was observed in the leaves and roots of $B$. napus cultivars. Intermediate values of these contents were noted at 200 and $400 \mu \mathrm{M}$ Be levels.
Glutathione reductase (GR) has ability to recycle the oxidized form of glutathione (GSSG) back to its reduced form (GSH) by maintaining higher GSH/GSSG ratio, which is required for the cellular protection against oxidative damage. Alterations in the activities of studied antioxidant enzymes were observed with the increase in Be levels (Figure 1). An increasing trend was found in SOD, POD, APX, and GR activities (except CAT) in both cultivars, that is, ZS 758 and Zheda 622. The better performance of ZS 758 as compared to Zheda 622 was reflected from their antioxidant activities under various levels of Be. The qRT-PCR analysis further confirmed the alterations in the above-mentioned antioxidant enzymes under various levels of Be (Figure 2). The transcript levels of studied antioxidant genes were significantly enhanced with the increase in Be levels (except CAT gene expression). The alterations in the transcript levels were insignificant at 100 and $200 \mu \mathrm{M}$ Be. The gene expression analysis in the leaves and roots of both $B$. napus cultivars was more prominent at $400 \mu \mathrm{M}$ Be level as compared to other treatments and control.

The ultrastructural variations were observed in leaf mesophyll and root tip cells of two B. napus cultivars (cvs. ZS 758 and Zheda 622) under control and $400 \mu \mathrm{M}$ Be level (Figures 3 and 4). All the organelles in the leaf mesophyll and root tip cells were observed as well-developed and matured under control conditions (Figures 3(a) and 3(b)). However, higher Be level $(400 \mu \mathrm{M})$ showed markedly damaged leaf mesophyll 

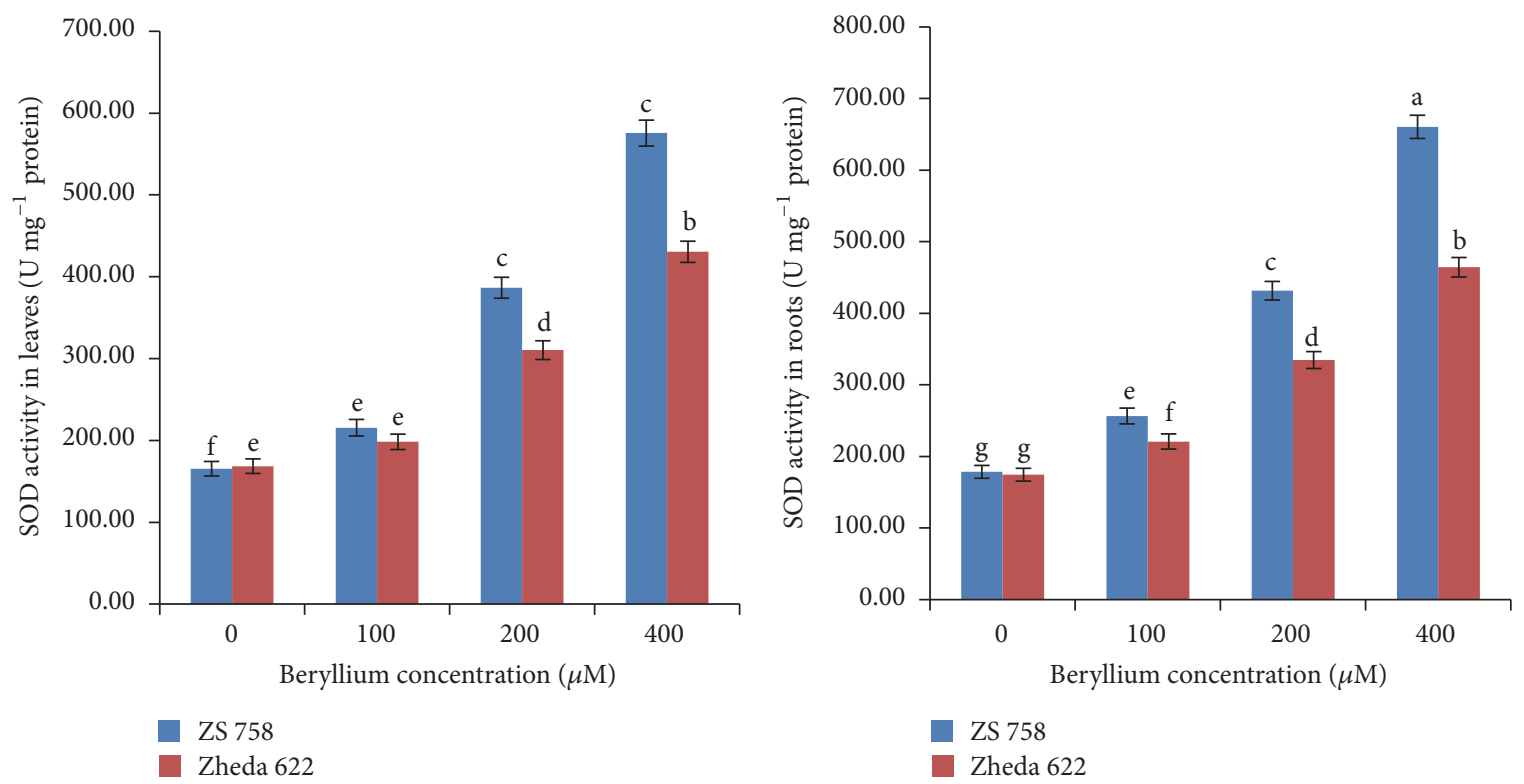

(a)
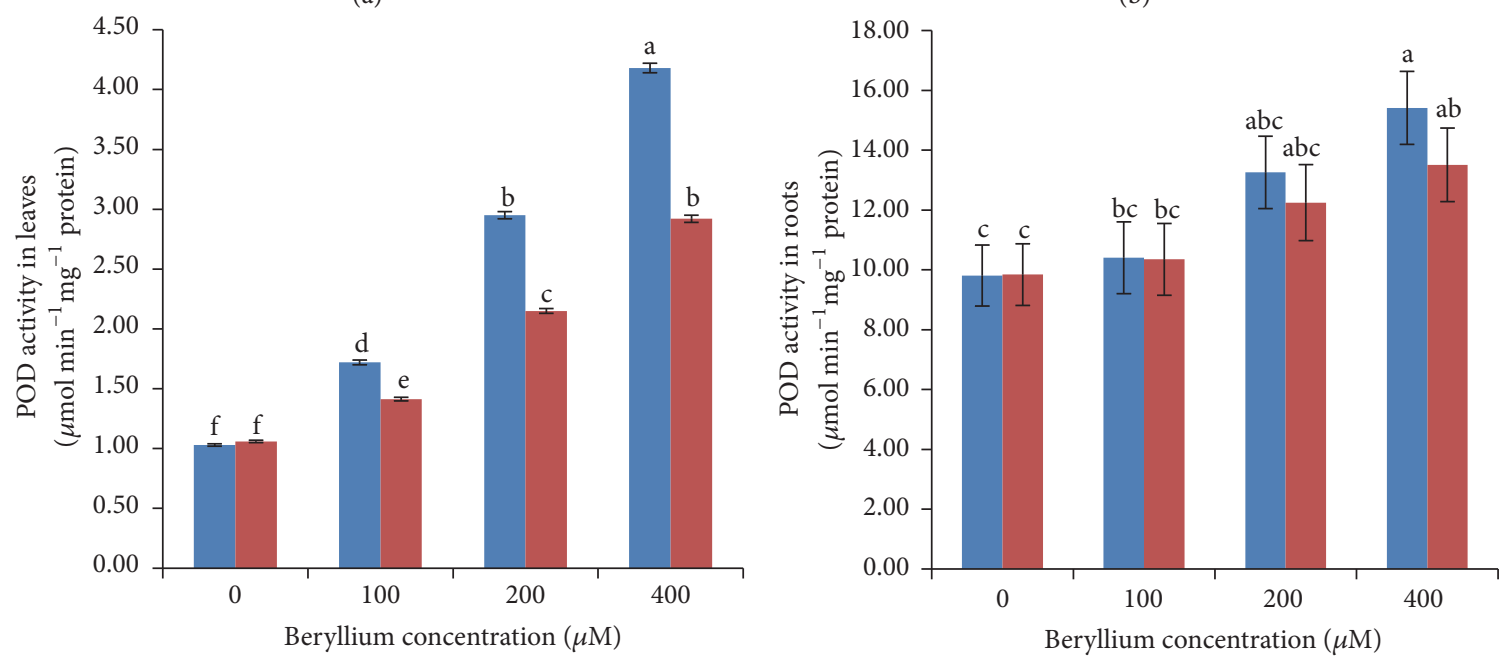

ZS 758

Zheda 622

(c)

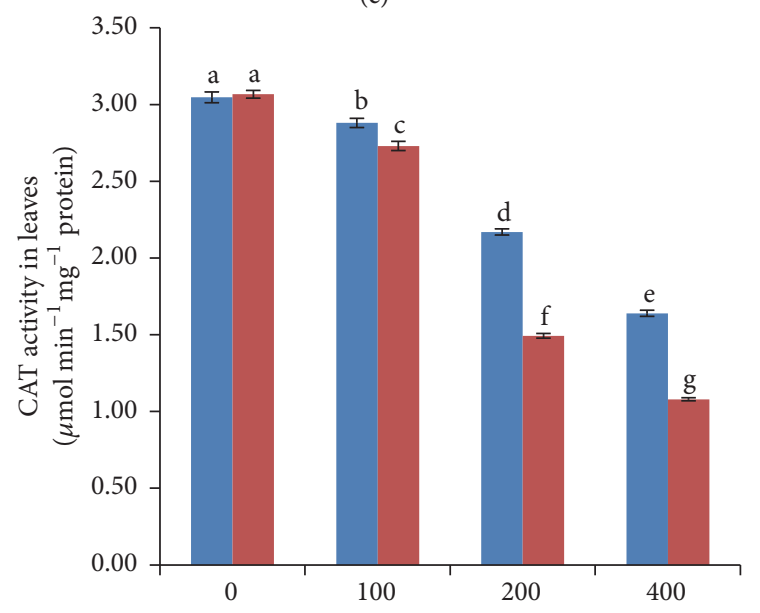

Beryllium concentration $(\mu \mathrm{M})$

ZS 758

Zheda 622

(e) 


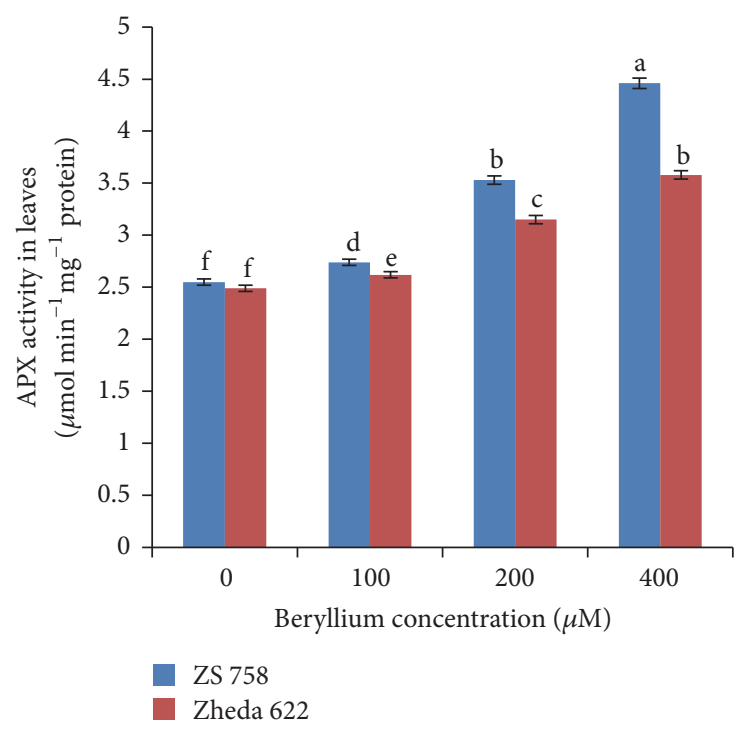

(g)

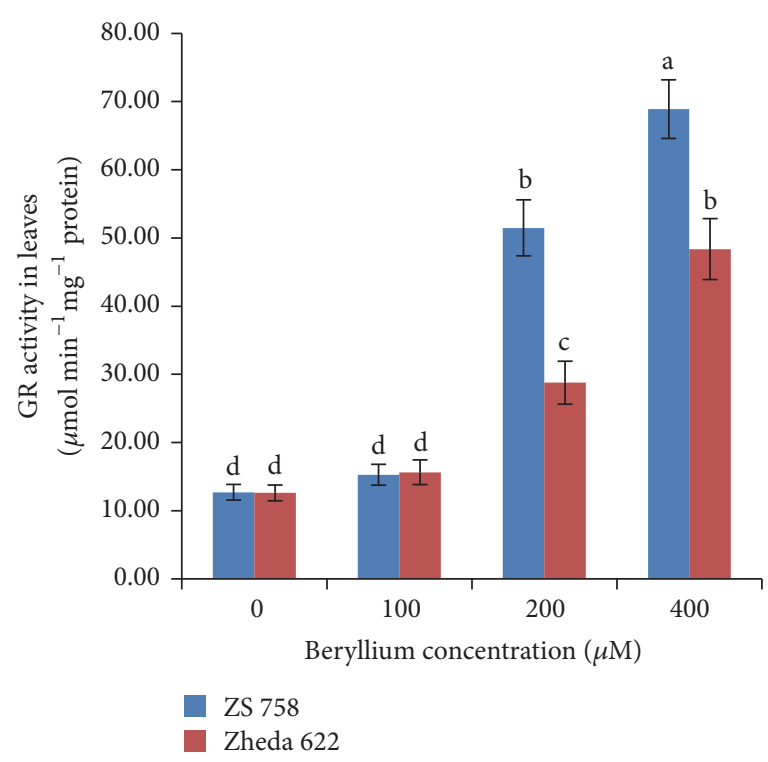

(i)

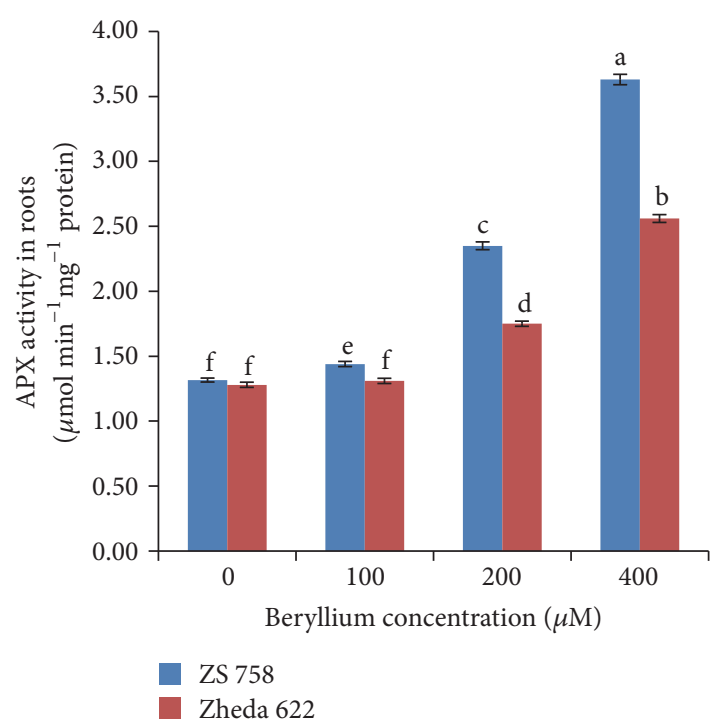

(h)

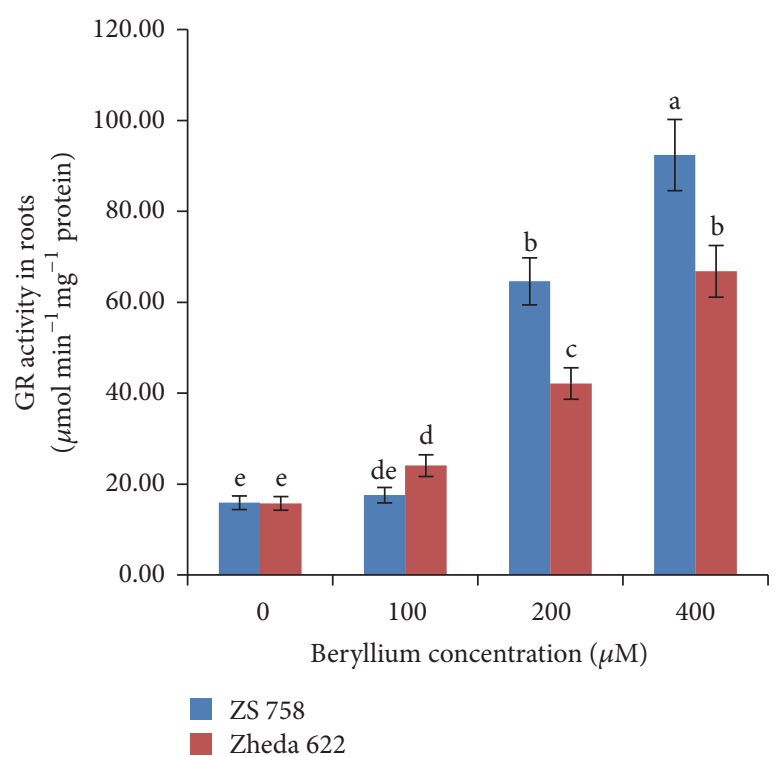

(j)

FIGURE 1: Effects of different concentrations of beryllium (Be) $(0,100,200$, and $400 \mu \mathrm{M})$ on the activities of (a, b) superoxide dismutase (SOD), $(c, d)$ guaiacol peroxidase (POD), (e, f) catalase (CAT), $(\mathrm{g}, \mathrm{h})$ ascorbate peroxidase (APX), and (i, j) glutathione reductase (GR), respectively, in the leaves and roots of 6-day-old seedlings of two Brassica napus cultivars (ZS 758, black seeded; Zheda 622, yellow seeded). Vertical bars represent standard deviation from three independent replicates. Means followed by the same letters are not significantly different by Duncan's multiple range test $(P<0.05)$.

(Figure 3) and root tip cells (Figure 4). At $400 \mu \mathrm{M}$ Be level, the alterations in leaf mesophyll cells were found including broken cell wall, damaged thylakoid membranes and chloroplast, deshaped and unmatured nucleus, and ruptured mitochondria. More damaging effects were revealed in Zheda 622 as compared to ZS 758 (Figures 3(c) and 3(d)). In roots, there were clear cell wall, rounded mitochondrial, nucleus with the well-developed nucleolus, and a clear nuclear membrane under control conditions (Figures 4(a) and 4(b)). Higher Be concentration $(400 \mu \mathrm{M})$ showed disrupt nuclear membrane, broken cell wall, damaged nucleus, and small size mitochondria (Figures 4(c) and 4(d)). More organelle damage was observed in Zheda 622 as compared to ZS 758. This showed that Zheda 622 was more sensitive to Be-toxicity than ZS 758.

\section{Discussion}

The accumulations of toxic metals in agriculture soils have become a major issue worldwide [43]. In plants, HMs cause oxidative stress that leads to cellular damage and ultimately inhibits the plant growth characteristics [44]. The 

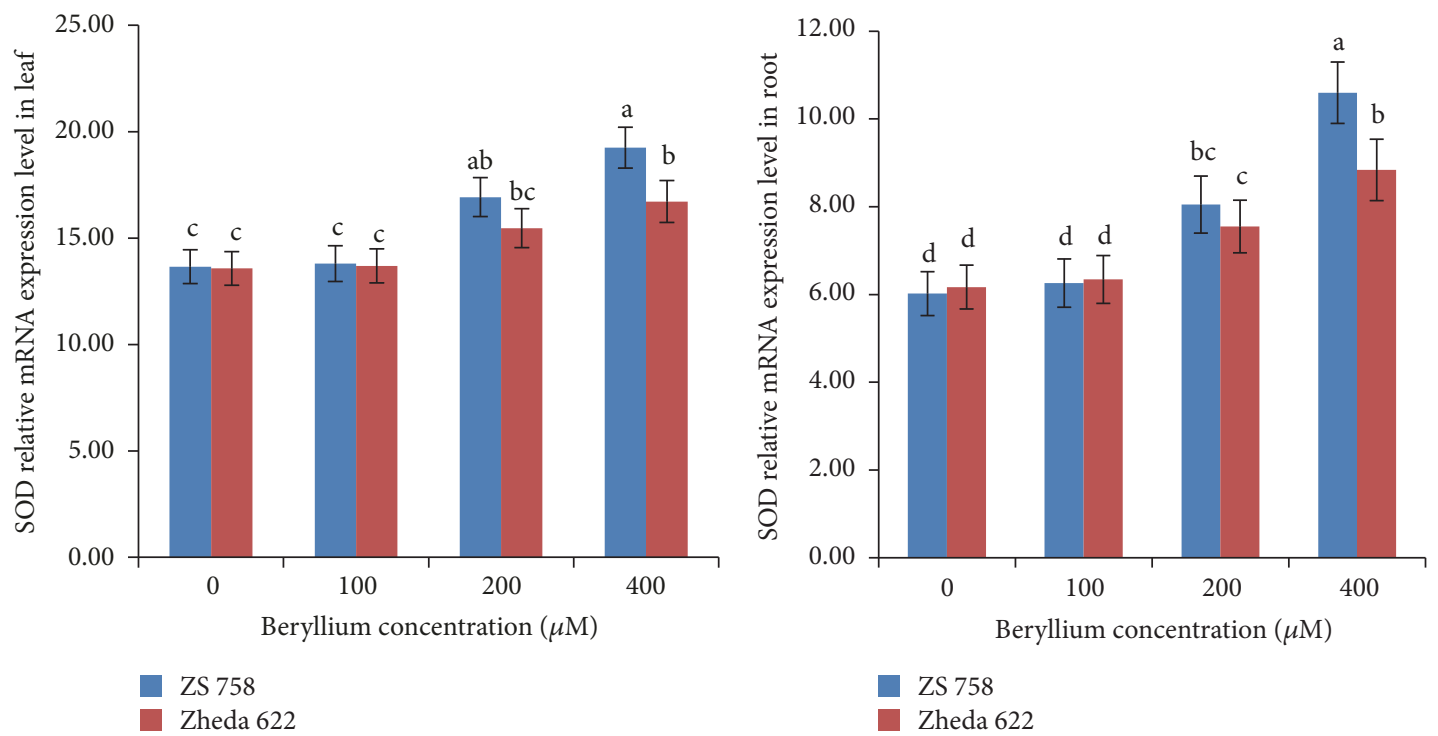

(a)

(b)
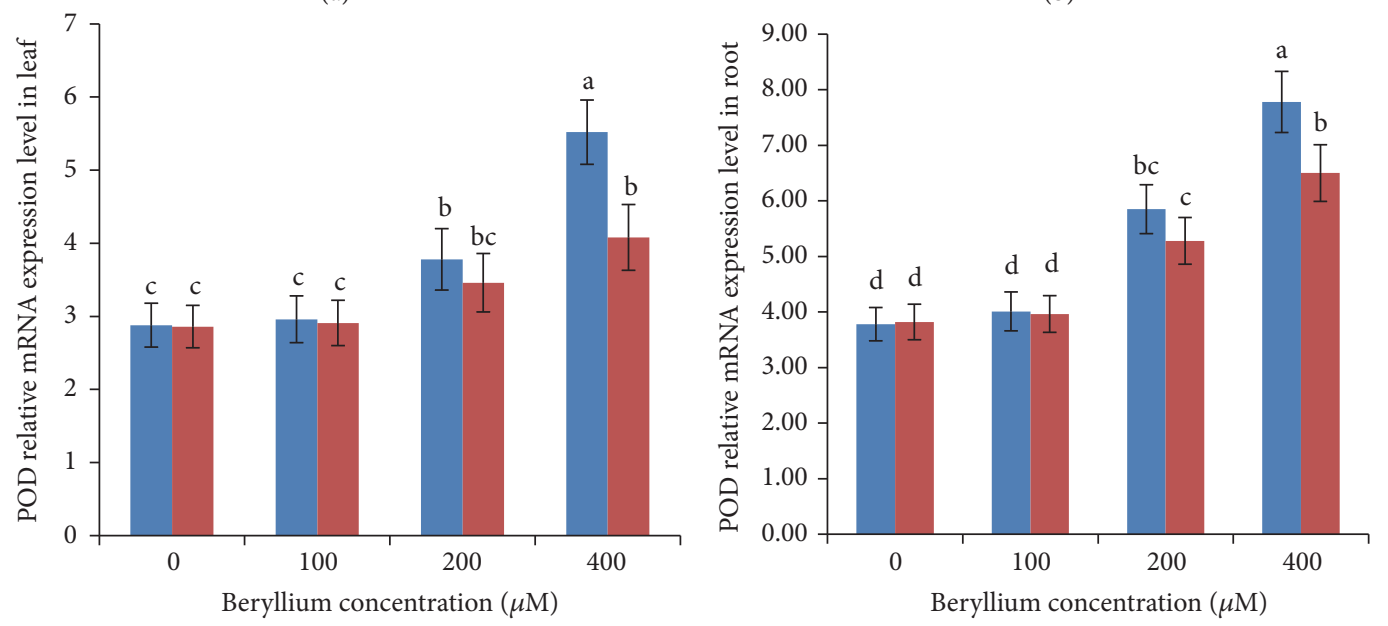

ZS 758

Zheda 622

Z Zheda 622

(c)

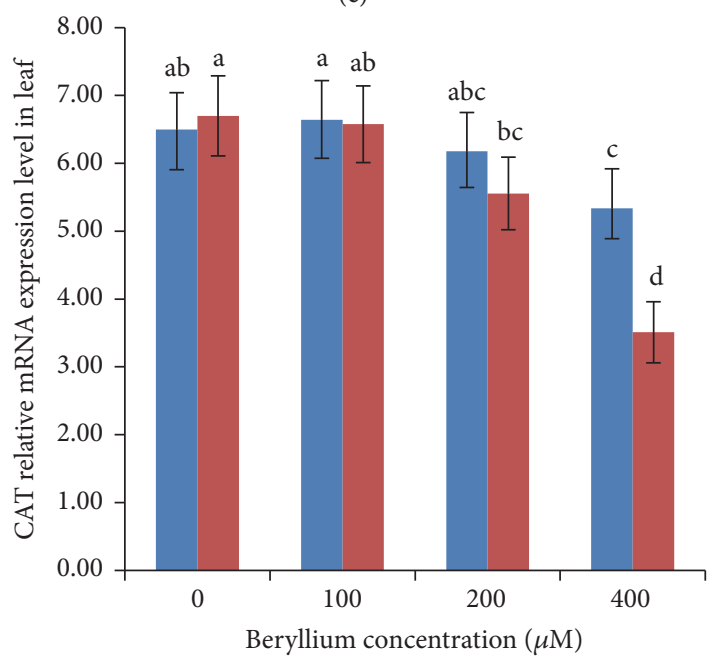

ZS 758

Zheda 622

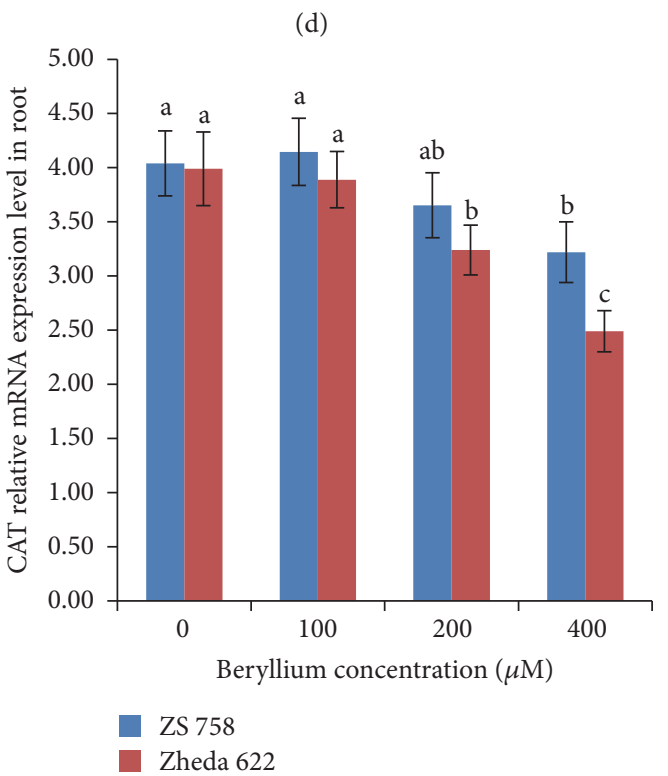

(f)

Figure 2: Continued. 


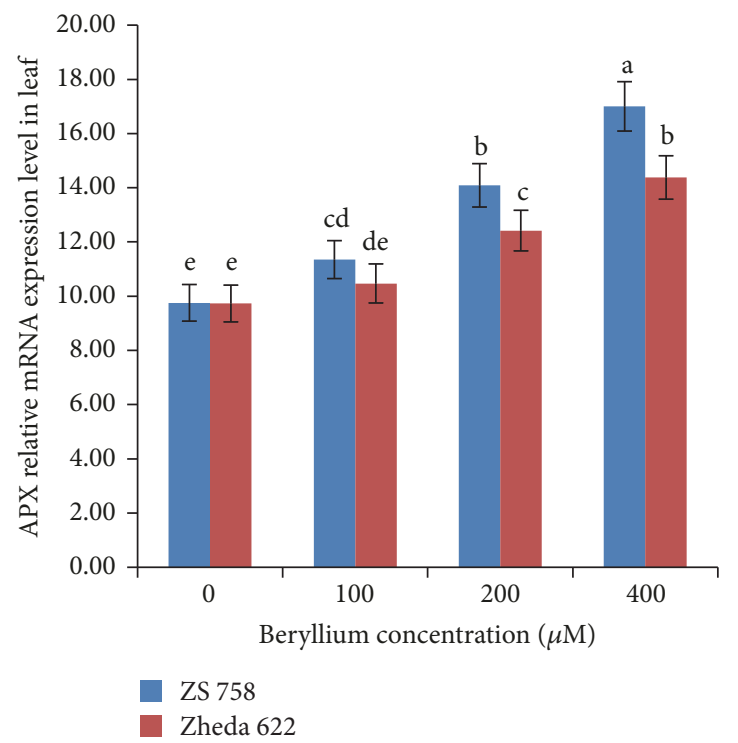

(g)

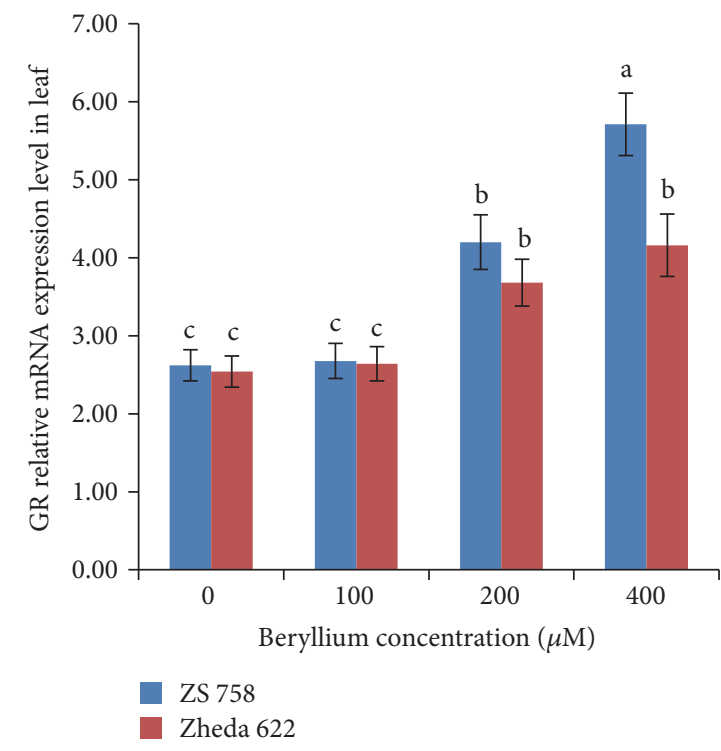

(i)

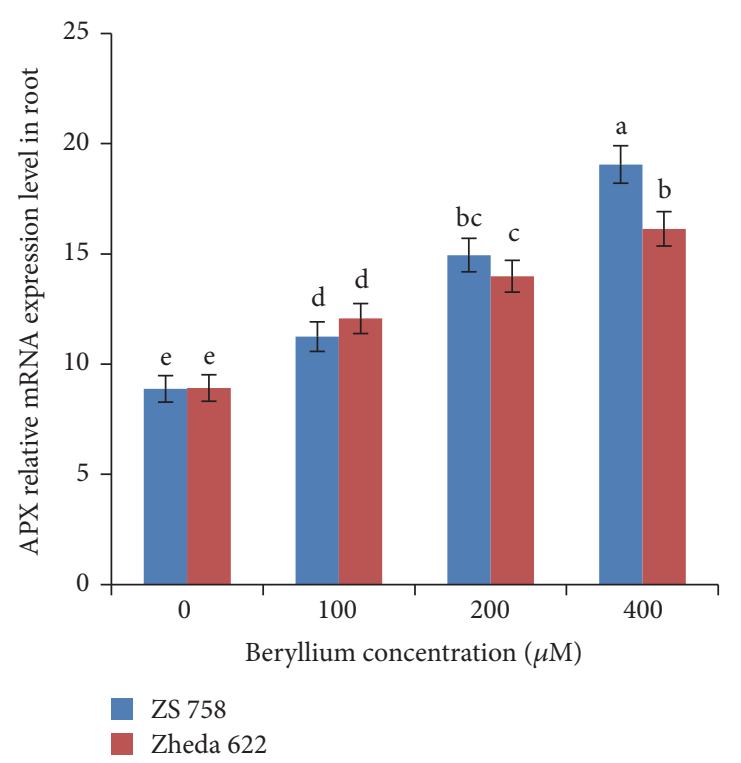

(h)

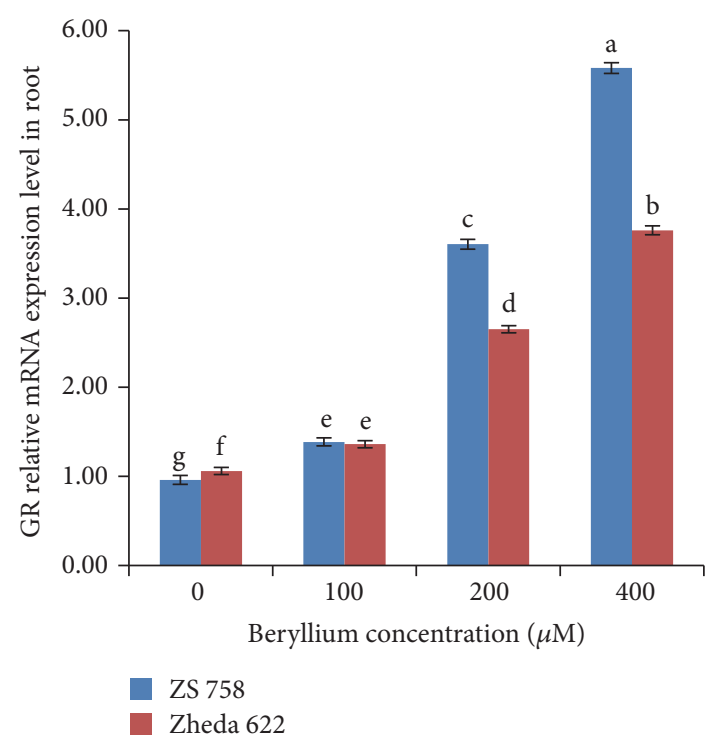

(j)

FIGURE 2: Effects of different concentrations of beryllium (Be) $(0,100,200$, and $400 \mu \mathrm{M})$ on the transcript level of (a, b) superoxide dismutase (SOD), (c, d) guaiacol peroxidase (POD), (e, f) catalase (CAT), (g, h) ascorbate peroxidase (APX), and (i, j) glutathione reductase (GR) related gene expression, respectively, in the leaves and roots of 6-day-old seedlings of two Brassica napus cultivars (ZS 758, black seeded; Zheda 622, yellow seeded). Vertical bars represent standard deviation from three independent replicates. Means followed by the same letters are not significantly different by Duncan's multiple range test $(P<0.05)$.

present study was conducted to investigate the Be-induced physiochemical, oxidative injury and ultrastructural changes in two B. napus cultivars, that is, ZS 758 and Zheda 622. Results showed that shoot and root lengths were decreased gradually with the increase in Be concentrations in both $B$. napus cultivars (Table 1). These results are in accordance with the findings of Kopyra and Gwóźdź [45] and Atici et al. [46] that HM toxicity inhibits the plant growth parameters. Hopkins [47] and Encina and Becerra [25] further confirmed that higher concentrations of Be deteriorated the plant root length. Plant biomass (root, stem, leaf), fresh and dry weights, was considerably reduced in both cultivars (ZS758, Zheda 622) under Be stress, especially in Zheda 622 (Table 1). Plants are prone to damage with $>1 \mathrm{ppm}$ of ionized Be. In cabbage, the higher Be concentration caused $50 \%$ yield reduction corresponding to $3000 \mathrm{mg} \mathrm{kg}^{-1}$ in the roots and $6 \mathrm{mg} \mathrm{kg}^{-1}$ dry weight in the leaves [24]. Similarly, current study showed obvious reduction in root dry biomass at higher Be concentrations in both Brassica cultivars (Table 1).

A significant reduction in the chlorophyll contents was observed under higher Be concentrations (200 and $400 \mu \mathrm{M})$, but lower Be concentration $(100 \mu \mathrm{M})$ showed insignificant 


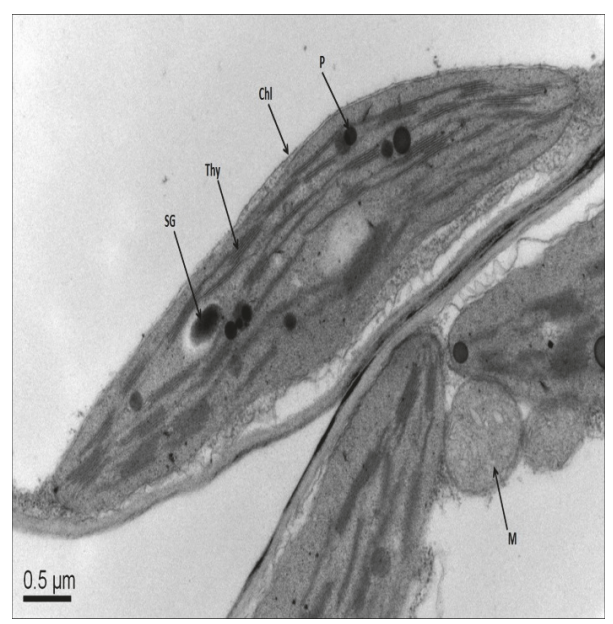

(a)

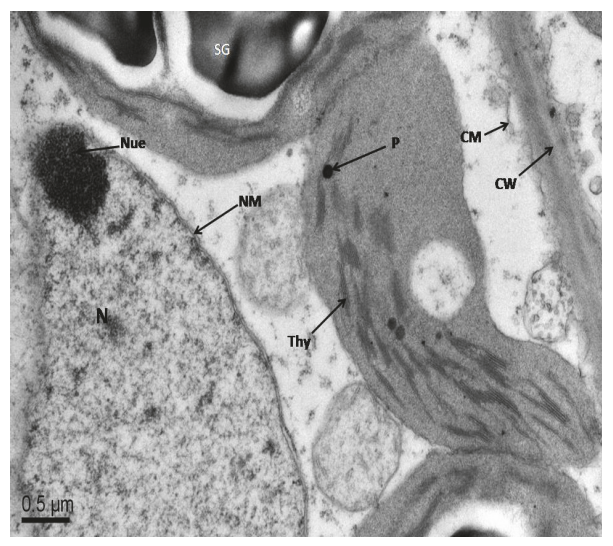

(c)

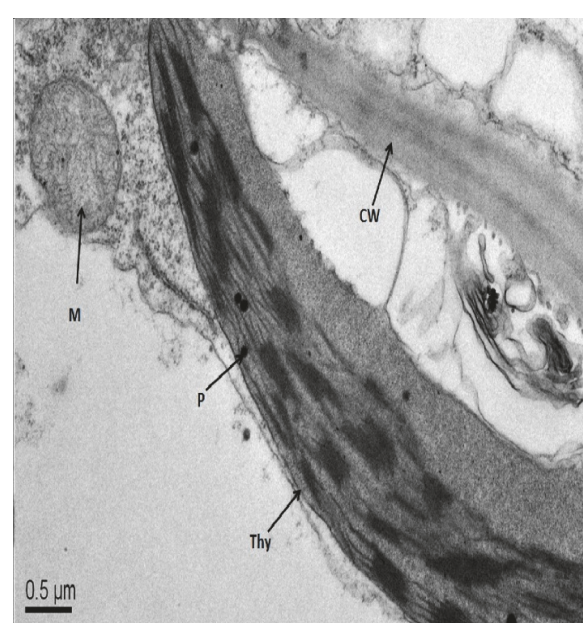

(b)

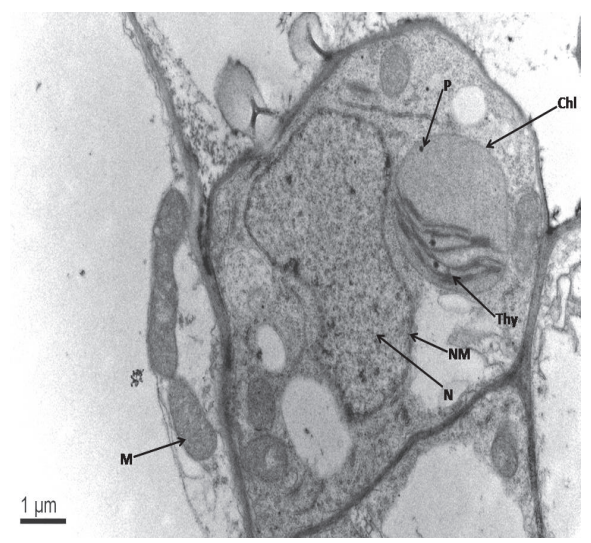

(d)

FIGURE 3: Electron micrographs of leaf mesophyll of 6-day-old seedlings of two cultivars of Brassica napus (ZS 758, black seeded; Zheda 622, yellow seeded) grown under control and $400 \mu \mathrm{M}$ Be. (a-b) leaf mesophyll cells of ZS 758 and Zheda 622 at control level, respectively, show well-developed cell wall (CW), chloroplasts (Chl), plastoglobuli (P), starch grain (SG), and mitochondria (M). (c) leaf mesophyll cell of ZS 758 at $400 \mu \mathrm{M}$ Be shows an unmatured nucleus (N) with nucleolus (Nue), disturbed nuclear membrane (NM), deshaped thylakoids (Thy), and small-sized plastoglobuli (P). (d) leaf mesophyll cell of Zheda 622 at $400 \mu \mathrm{M}$ Be shows damaged thylakoid membranes (Thy), disturbed nuclear membrane (NM), very small plastoglobuli (P), ruptured mitochondria (M), and chloroplast structures.

reduction in the leaves of both B. napus cultivars (Table 2). These findings were in accordance with Küpper et al. [48] and Ali et al. [2] that $\mathrm{Zn}$ and $\mathrm{Cd}$ application declined the chlorophyll contents in Arabidopsis and oilseed rape, respectively. This might be due to the disturbances in the protein complexes and photosynthetic apparatus that decline the chlorophyll contents under metal stress [49]. Carotenoids serve as antioxidants by scavenging free radicals, reduce cell injury, and lessen the damage in chloroplast membrane induced by HMs [50]. Singh and Sinha [51] investigated a decrease in Rubisco activity that plays a key role in the reduction of pigment concentration, as observed in the current study (Table 2) which revealed that higher concentrations of Be reduced the total soluble protein (TSP) contents in both $B$. napus cultivars (Table 2). These findings are in line with the results of Gunes et al. [52] in which they found that HM stress declined TSP contents in B. juncea.
Malondialdehyde (MDA) is an important indicator of oxidative damage induced by metal stress [53]. MDA contents in leaves and roots were enhanced with the increase in $\mathrm{Be}$ concentrations in both B. napus cultivars (Table 3). Similar findings were observed by Romney et al. [26]; that is, higher Be stress increased the lipid peroxidation rate. The current study found higher production of ROS with the increase in Be concentrations in both B. napus cultivars (Table 3). The cultivar Zheda 622 was found more sensitive to ROS as compared to ZS 758, which is in accordance with the previous findings that tolerant plants showed less accumulation of ROS as compared to sensitive one [6]. Liu et al. [54] also reported an increase in $\mathrm{H}_{2} \mathrm{O}_{2}$ level in Pteris vittata $\mathrm{L}$. and Pteris ensiformis L. This might be due to the cellular damage induced by HM stress that ultimately causes the cell death.

Plants have developed various strategies to scavenge the ROS and detoxify abiotic stress [55]. The induction of 


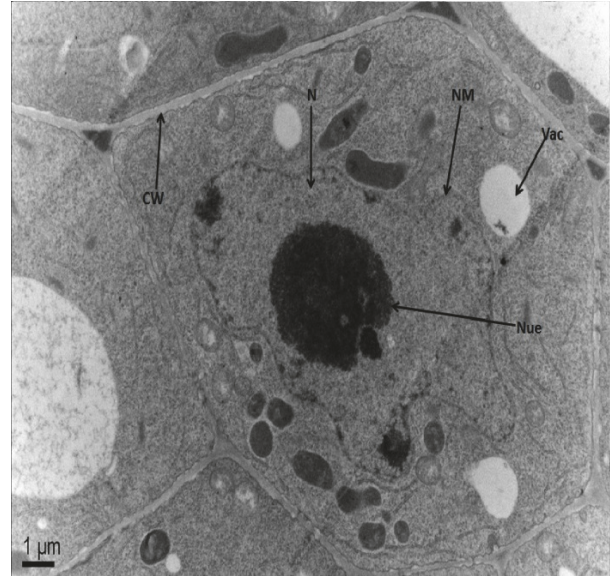

(a)

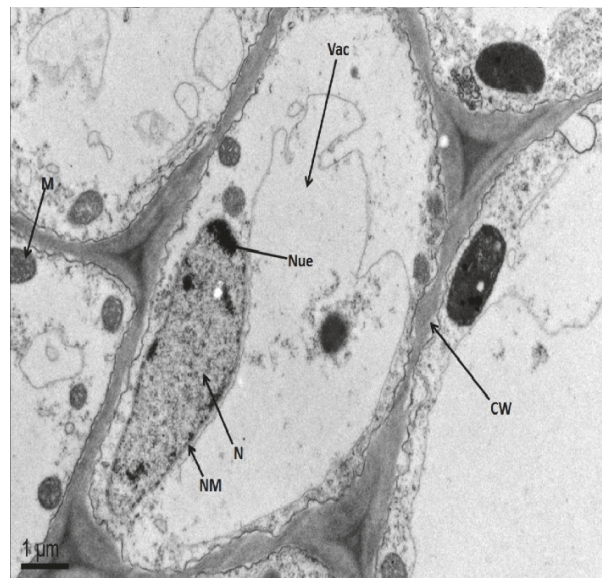

(c)

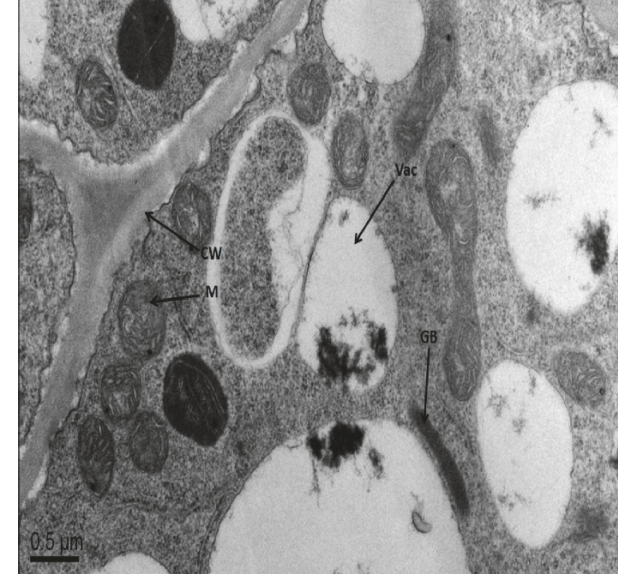

(b)

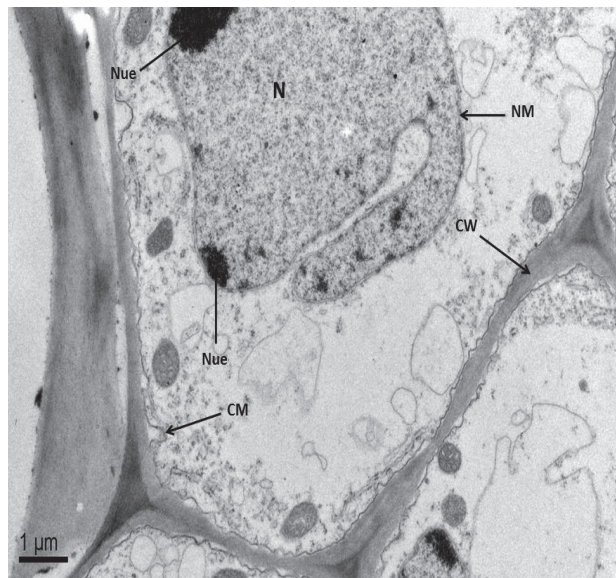

(d)

FIGURE 4: Electron micrographs of root cells of 6-day-old seedlings of two cultivars of Brassica napus (ZS 758, black seeded; Zheda 622, yellow seeded) grown at control and with $400 \mu \mathrm{M}$ Be. (a-b) root cells of ZS 758 and Zheda 622 at control level, respectively, show well-developed nucleus (N) with nucleolus (Nue), vacuole (Vac), nuclear membrane (NM), cell wall (CW), and well-developed mitochondria (M) as well as Golgi bodies. (c) root cell of ZS 758 at $400 \mu \mathrm{M}$ Be shows a damaged cell wall (CW), deshaped nucleus (N) with nucleolus (Nue), small-sized mitochondria (M), disturbed large vacuole (Vac), and disrupted nuclear membrane (NM). (d) root cell of Zheda 622 at $400 \mu \mathrm{M}$ Be shows a broken cell wall $(\mathrm{CW})$, disturbed nucleus $(\mathrm{N})$ with nucleolus (Nue), damaged cell membrane (CM), and nuclear membrane (NM).

antioxidant defense system prevents the plants from oxidative damage [56]. In the present study, Be-toxicity triggered the antioxidant enzymatic defense system including SOD, POD, APX, and GR activities (except CAT) in both B. napus cultivars (Figure 1). An enhancement in SOD activity in the leaves and roots of both B. napus cultivars (ZS 758 and Zheda 622) was found with the increase in Be levels (Figures 1(a) and 1(b)), which confirms the results of previous study by Gupta et al. [57]. Similarly, the increase in POD activity was noted in both B. napus cultivars under Be stress (Figures 1(c) and 1(d)), which is similar to the investigations carried out by Qureshi et al. [58] in Arabidopsis paniculata. Furthermore, CAT activity was reduced with the increase of Be concentrations in both B. napus cultivars (Figures $1(\mathrm{e})$ and $1(\mathrm{f})$ ). The reduction in CAT activity under Be stress might be due to enhanced $\mathrm{H}_{2} \mathrm{O}_{2}$ accumulation that results in its inactivation [59]. The activities of GR and APX were increased in both B. napus cultivars with the increase in Be concentrations (Figures $1(\mathrm{~g})-1(\mathrm{j}))$. These findings were in line with Masood et al. [60] that HM stress improves the GR and APX activities in $H$. annuus and B. juncea. The increase in SOD, POD, APX, and GR activities proved that both cultivars have the ability to cope with HM stress and adapt themselves against Be stress by modulating the antioxidant defense system. This activated antioxidant defense system may assist plants in removing or scavenging the excess ROS production and hinder the lipid peroxidation [2]. Recently, Shah et al. [19] also suggested that Be-toxicity can alter enzyme activities by disturbing their metabolic functions. The seedlings of Zheda 622 have shown more oxidative stress due to the higher production of ROS under Be stress than those of black seeded cultivar ZS 758, which showed higher antioxidant activities (Figure 1).

The transcript levels of antioxidant genes including SOD, POD, GR, and APX were increased (decline in CAT gene) in 
the leaves and roots of both B. napus cultivars under Be stress (Figure 2). The upregulation of these above-mentioned genes was increased significantly in cultivar ZS 758 as compared to the sensitive cultivar Zheda 622. This upregulation in different genes suggested their direct involvement in defenserelated mechanisms under Be stress that exhibited the Betolerance in B. napus cultivars. Besides, plants also triggered their nonenzymatic antioxidant system such as GSH and GSSG levels to strengthen their protection against stress conditions [61]. Results showed that both GSH and GSSG were increased with the increase in Be stress in the leaves and roots of both cultivars (Table S2). Similarly, Gill et al. [6] also investigated the protective role of GSH/GSSG ratio in reducing the damage induced by $\mathrm{Cr}$ stress in $B$. napus.

The ultrastructural alterations in leaf mesophyll and root tip cells were observed under different Be levels (Figures 3 and 4). Higher Be levels markedly damaged the thylakoids membrane, starch grain, plastoglobuli, mitochondrial, and chloroplast structures. More obvious alterations were observed in Zheda 622 as compared to ZS 758. Similar damage in the leaf mesophyll and root tip cell ultrastructures was investigated in B. napus against $\mathrm{Cr}$ stress [6]. In conclusion, the present study highlighted that both $B$. napus cultivars have shown different capability to face Be-toxicity. Our findings depicted that Be-toxicity had significantly declined the plant growth traits, biomass production, chlorophyll contents, and total soluble protein contents in both cultivars. The application of Be has caused oxidative damage by inducing ROS and MDA contents in a dose-dependent manner. The improvement in antioxidant enzyme activities including SOD, POD, APX, and GR (except CAT) was observed in both $B$. napus cultivars under Be stress. Antioxidant enzymes were further confirmed by gene expression analysis. The upregulation of the abovementioned genes has suggested their direct involvement in defense mechanism under Be stress. Additionally, the increase in nonenzymatic antioxidants (GSH, GSSG) against studied Be levels showed plant protection against stress conditions. The electron microscopic study revealed that the ultrastructural damage in leaf mesophyll and root tip cells was more prominent in Zheda 622 as compared to ZS 758. These findings showed that Zheda 622 proved to be more sensitive cultivar than ZS 758. The present study would be of great interest to scientists working on phytoremediation and related areas. However, further investigations are required regarding Be-toxicity in soil-based environment.

\section{Conflicts of Interest}

The authors have declared no conflicts of interest.

\section{Acknowledgments}

The authors would like to appreciate the funding support by the Jiangsu Collaborative Innovation Center for Modern Crop Production, the Sino-German Research project (GZ 1362), the Science and Technology Department of Zhejiang Province (2016C02050-8) and Quzhou Municipality (2016Y025), the National Natural Science Foundation of China (31650110476), and the 111 project (B06014).

\section{Supplementary Materials}

Table S1: oligonucleotide sequences of antioxidants related transcripts used in qRT-PCR analysis. Table S2: effects of different concentrations of beryllium (Be) on GSH and GSSG $\left[\mu \mathrm{molg}^{-1}\right.$ (d.m.)] contents in the leaves and roots of two Brassica napus cultivars. (Supplementary Materials)

\section{References}

[1] C. J. Allender and G. J. King, "Origins of the amphiploid species Brassica napus L. investigated by chloroplast and nuclear molecular markers," BMC Plant Biology, vol. 10, article no. 54, 2010.

[2] B. Ali, P. Qian, R. Jin et al., "Physiological and ultra-structural changes in Brassica napus seedlings induced by cadmium stress," Biologia Plantarum, vol. 58, no. 1, pp. 131-138, 2014.

[3] H. Tan, X. Yang, F. Zhang et al., "Enhanced seed oil production in canola by conditional expression of brassica napus LEAFY COTYLEDON1 and LEC1-LIKE in developing seeds," Plant Physiology, vol. 156, no. 3, pp. 1577-1588, 2011.

[4] H. Meng, S. Hua, I. H. Shamsi, G. Jilani, Y. Li, and L. Jiang, "Cadmium-induced stress on the seed germination and seedling growth of Brassica napus L., and its alleviation through exogenous plant growth regulators," Plant Growth Regulation, vol. 58, no. 1, pp. 47-59, 2009.

[5] R. Yu, J. Ji, X. Yuan, Y. Song, and C. Wang, "Accumulation and translocation of heavy metals in the canola (Brassica napus L.)soil system in Yangtze River Delta, China," Plant and Soil, vol. 353, no. 1-2, pp. 33-45, 2012.

[6] R. A. Gill, L. Zang, B. Ali et al., "Chromium-induced physiochemical and ultrastructural changes in four cultivars of Brassica napus L.," Chemosphere, vol. 120, pp. 154-164, 2015.

[7] P. M. A. Ramzani, W.-U. Khan, M. Iqbal et al., "Effect of different amendments on rice (Oryza sativa L.) growth, yield, nutrient uptake and grain quality in Ni-contaminated soil," Environmental Science and Pollution Research, vol. 23, no. 18, pp. 18585-18595, 2016.

[8] S. Anwar, M. F. Nawaz, S. Gul, M. Rizwan, S. Ali, and A. Kareem, "Uptake and distribution of minerals and heavy metals in commonly grown leafy vegetable species irrigated with sewage water," Environmental Modeling \& Assessment, vol. 188, no. 9, article no. 541, 2016.

[9] I. E. Zaheer, S. Ali, M. Rizwan et al., "Citric acid assisted phytoremediation of copper by Brassica napus L," Ecotoxicology and Environmental Safety, vol. 120, pp. 310-317, 2015.

[10] S. De Maria, M. Puschenreiter, and A. R. Rivelli, "Cadmium accumulation and physiological response of sunflower plants to Cd during the vegetative growing cycle," Plant Soil and Environment, vol. 59, no. 6, pp. 254-261, 2013.

[11] J.-D. Lin, C. Handschin, and B. M. Spiegelman, "Metabolic control through the PGC-1 family of transcription coactivators," Cell Metabolism, vol. 1, no. 6, pp. 361-370, 2005.

[12] W. Maksymiec, "Signaling responses in plants to heavy metal stress," Acta Physiologiae Plantarum, vol. 29, no. 3, pp. 177-187, 2007.

[13] J. Molas, "Changes of chloroplast ultrastructure and total chlorophyll concentration in cabbage leaves caused by excess of organic Ni(II) complexes," Environmental and Experimental Botany, vol. 47, no. 2, pp. 115-126, 2002. 
[14] B. Ali, B. Wang, S. Ali et al., "5-Aminolevulinic Acid Ameliorates the Growth, Photosynthetic Gas Exchange Capacity, and Ultrastructural Changes Under Cadmium Stress in Brassica napus L," Journal of Plant Growth Regulation, vol. 32, no. 3, pp. 604-614, 2013.

[15] A. Piotrowska, A. Bajguz, B. Godlewska-Zyłkiewicz, R. Czerpak, and M. Kamińska, "Jasmonic acid as modulator of lead toxicity in aquatic plant Wolffia arrhiza (Lemnaceae)," Environmental and Experimental Botany, vol. 66, no. 3, pp. 507-513, 2009.

[16] H. H. Willis and H. K. Florig, "Potential exposures and risks from beryllium-containing products," Risk Analysis, vol. 22, no. 5, pp. 1019-1033, 2002.

[17] G. Armiento, F. Bellatreccia, C. Cremisini, G. Della Ventura, E. Nardi, and R. Pacifico, "Beryllium natural background concentration and mobility: A reappraisal examining the case of high Be-bearing pyroclastic rocks," Environmental Modeling \& Assessment, vol. 185, no. 1, pp. 559-572, 2013.

[18] R. W. Dabeka, X. L. Cao, and J. Moisey, Dietary intakes of trace elements for the years 2003-2007, Food Research Division, Bureau of Chemical Safety, Health Products and Food Branch, Health Canada, Ottawa, Canada, 2010.

[19] A. N. Shah, M. Tanveer, S. Hussain, and G. Yang, "Beryllium in the environment: Whether fatal for plant growth?" Reviews in Environmental Science and Bio/Technology, vol. 15, no. 4, pp. 549-561, 2016.

[20] J. R. Miller, K. A. Hudson-Edwards, P. J. Lechler, D. Preston, and M. G. Macklin, "Heavy metal contamination of water, soil and produce within riverine communities of the Río Pilcomayo basin, Bolivia," Science of the Total Environment, vol. 320, no. 2-3, pp. 189-209, 2004.

[21] K. S. Sajwan, W. H. Ornes, and T. V. Youngblood, "Beryllium phytotoxicity in soybeans," Water, Air, \& Soil Pollution, vol. 86, pp. 117-124, 1996.

[22] T. Hara, T. Furuta, Y. Sonoda, and I. Iwai, "Growvth response of cabbage plants to beryllium and strontium under water culture conditions," Soil Science \& Plant Nutrition, vol. 23, no. 3, pp. 373-380, 1977.

[23] D. I. Kaplan, K. S. Sajwan, D. C. Adriano, and S. Gettier, "Phytoavailability and toxicity of beryllium and vanadium," Water, Air, \& Soil Pollution, vol. 53, pp. 203-212, 1990.

[24] N. D. Agrawal, S. K. Nirala, S. Shukla, and R. Mathur, "Coadministration of adjuvants along with Moringa oleifera attenuates beryllium-induced oxidative stress and histopathological alterations in rats," Pharmaceutical Biology, vol. 53, no. 10, pp. 1465-1473, 2015.

[25] C. L. Encina and J. Becerra, "Inhibition of plant cytokinesis by beryllium and its reversion by calcium," Environmental and Experimental Botany, vol. 26, no. 1, pp. 75-80, 1986.

[26] E. M. Romney, J. D. Childress, and G. V. Alexander, "Beryllium and the growth of bush beans," Science, vol. 135, no. 3506, pp. 786-787, 1962.

[27] W. F. Zhang, F. Zhang, R. Raziuddin et al., "Effects of 5aminolevulinic acid on oilseed rape seedling growth under herbicide toxicity stress," Journal of Plant Growth Regulation, vol. 27, no. 2, pp. 159-169, 2008.

[28] R. J. Porra, W. A. Thompson, and P. E. Kriedemann, "Determination of accurate extinction coefficients and simultaneous equations for assaying chlorophyll $\mathrm{a}$ and $\mathrm{b}$ extracted with four different solvents: verification of the concentration of chlorophyll standards by atomic absorption spectroscopy," Biochimica et Biophysica Acta, vol. 975, pp. 384-394, 1989.
[29] W. Zhou and M. Leul, "Uniconazole-induced tolerance of rape plants to heat stress in relation to changes in hormonal levels, enzyme activities and lipid peroxidation," Plant Growth Regulation, vol. 27, no. 2, pp. 99-104, 1999.

[30] H. J. Gong, K. M. Chen, Z. G. Zhao, G. C. Chen, and W. J. Zhou, "Effects of silicon on defense of wheat against oxidative stress under drought at different developmental stages," Biologia Plantarum, vol. 52, no. 3, pp. 592-596, 2008.

[31] V. Velikova, I. Yordanov, and A. Edreva, "Oxidative stress and some antioxidant systems in acid rain-treated bean plants protective role of exogenous polyamines," Journal of Plant Sciences, vol. 151, no. 1, pp. 59-66, 2000.

[32] B. Halliwell, J. M. C. Gutteridge, and O. I. Aruoma, "The deoxyribose method: a simple 'test-tube' assay for determination of rate constants for reactions of hydroxyl radicals," Analytical Biochemistry, vol. 165, no. 1, pp. 215-219, 1987.

[33] M. Y. Law, S. A. Charles, and B. Halliwell, "Glutathione and ascorbic acid in spinach (Spinacia oleracea) chloroplasts. The effect of hydrogen peroxide and of Paraquat," Biochemical Journal, vol. 210, no. 3, pp. 899-903, 1983.

[34] X. Z. Zhang, "The measurement and mechanism of lipid peroxidation and SOD, POD and CAT activities in biological system," in Research Methods, X. Z. Zhang, Ed., pp. 208-211, 1992.

[35] M. Leul and W. J. Zhou, "Alleviation of waterlogging damage in winter rape by uniconazole application: Effects on enzyme activity, lipid peroxidation, and membrane integrity," Journal of Plant Growth Regulation, vol. 18, no. 1, pp. 9-14, 1999.

[36] H. Aebi, “[13] Catalase in vitro," Methods in Enzymology, vol. 105, pp. 121-126, 1984.

[37] Y. Nakano and K. Asada, "Hydrogen peroxide is scavenged by ascorbate-specific peroxidase in spinach chloroplasts," Plant \& Cell Physiology (PCP), vol. 22, no. 5, pp. 867-880, 1981.

[38] M. Jiang and J. Zhang, "Water stress-induced abscisic acid accumulation triggers the increased generation of reactive oxygen species and up-regulates the activities of antioxidant enzymes in maize leaves," Journal of Experimental Botany, vol. 53, no. 379, pp. 2401-2410, 2002.

[39] M. M. Bradford, "A rapid and sensitive method for the quantitation of microgram quantities of protein utilizing the principle of protein dye binding," Analytical Biochemistry, vol. 72, no. 1-2, pp. 248-254, 1976.

[40] K. J. Livak and T. D. Schmittgen, "Analysis of relative gene expression data using real time quantitative PCR and the $2^{-\Delta \Delta C t}$ method," Methods, vol. 25, no. 4, pp. 402-408, 2001.

[41] T. M. Mwamba, S. Ali, B. Ali et al., "Interactive effects of cadmium and copper on metal accumulation, oxidative stress, and mineral composition in Brassica napus," International Journal of Environmental Science and Technology, vol. 13, no. 9, pp. 2163-2174, 2016.

[42] Y.-F. Lin and M. G. M. Aarts, "The molecular mechanism of zinc and cadmium stress response in plants," Cellular and Molecular Life Sciences, vol. 69, no. 19, pp. 3187-3206, 2012.

[43] R. Fernández, A. Bertrand, A. Casares, R. García, A. González, and R. S. Tamés, "Cadmium accumulation and its effect on the in vitro growth of woody fleabane and mycorrhized white birch," Environmental Pollution, vol. 152, no. 3, pp. 522-529, 2008.

[44] S. K. Yadav, "Heavy metals toxicity in plants: an overview on the role of glutathione and phytochelatins in heavy metal stress tolerance of plants," South African Journal of Botany, vol. 76, no. 2, pp. 167-179, 2010. 
[45] M. Kopyra and E. A. Gwóźdź, "Nitric oxide stimulates seed germination and counteracts the inhibitory effect of heavy metals and salinity on root growth of Lupinus luteus," Plant Physiology and Biochemistry, vol. 41, no. 11-12, pp. 1011-1017, 2003.

[46] Ö. Atici, G. Ağar, and P. Battal, "Changes in phytohormone contents in chickpea seeds germinating under lead or zinc stress," Biologia Plantarum, vol. 49, no. 2, pp. 215-222, 2005.

[47] H. T. Hopkins, "Inhibition of growth by benzene hexachloride isomers and protective effect of glucose as measured by cell counting technique," Plant Physiology, vol. 27, no. 3, pp. 526540,1952 .

[48] H. Küpper, E. Lombi, F.-J. Zhao, and S. P. McGrath, "Cellular compartmentation of cadmium and zinc in relation to other elements in the hyperaccumulator Arabidopsis halleri," Planta, vol. 212, no. 1, pp. 75-84, 2000.

[49] R. Czerpak, A. Piotrowska, and K. Szulecka, "Jasmonic acid affects changes in the growth and some components content in alga Chlorella vulgaris," Acta Physiologiae Plantarum, vol. 28, no. 3, pp. 195-203, 2006.

[50] F. Pietrini, M. A. Iannelli, S. Pasqualini, and A. Massacci, "Interaction of Cadmium with Glutathione and Photosynthesis in Developing Leaves and Chloroplasts of Phragmites australis (Cav.) Trin. ex Steudel," Plant Physiology, vol. 133, no. 2, pp. 829$837,2003$.

[51] S. Singh and S. Sinha, "Accumulation of metals and its effects in Brassica juncea (L.) Czern. (cv. Rohini) grown on various amendments of tannery waste," Ecotoxicology and Environmental Safety, vol. 62, no. 1, pp. 118-127, 2005.

[52] A. Gunes, A. Inal, E. G. Bagci, S. Coban, and O. Sahin, "Silicon increases boron tolerance and reduces oxidative damage of wheat grown in soil with excess boron," Biologia Plantarum, vol. 51, no. 3, pp. 571-574, 2007.

[53] N. Singh, L. Q. Ma, M. Srivastava, and B. Rathinasabapathi, "Metabolic adaptations to arsenic-induced oxidative stress in Pteris vittata $\mathrm{L}$ and Pteris ensiformis L," Journal of Plant Sciences, vol. 170, no. 2, pp. 274-282, 2006.

[54] H. Liu, D. Weisman, Y.-B. Ye et al., "An oxidative stress response to polycyclic aromatic hydrocarbon exposure is rapid and complex in Arabidopsis thaliana," Journal of Plant Sciences, vol. 176, no. 3, pp. 375-382, 2009.

[55] P. Sharma, A. B. Jha, R. S. Dubey, and M. Pessarakli, "Reactive oxygen species, oxidative damage, and antioxidative defense mechanism in plants under stressful conditions," Journal of Botany, vol. 2012, Article ID 217037, 26 pages, 2012.

[56] M. Shri, S. Kumar, D. Chakrabarty et al., "Effect of arsenic on growth, oxidative stress, and antioxidant system in rice seedlings," Ecotoxicology and Environmental Safety, vol. 72, no. 4, pp. 1102-1110, 2009.

[57] M. Gupta, P. Sharma, N. B. Sarin, and A. K. Sinha, "Differential response of arsenic stress in two varieties of Brassica juncea L.," Chemosphere, vol. 74, no. 9, pp. 1201-1208, 2009.

[58] M. I. Qureshi, M. Z. Abdin, S. Qadir, and M. Iqbal, "Leadinduced oxidative stress and metabolic alterations in Cassia angustifolia Vahl.," Biologia Plantarum, vol. 51, no. 1, pp. 121-128, 2007.

[59] S. K. Panda and S. Choudhury, "Chromium stress in plants," Brazilian Journal of Plant Physiology, vol. 17, no. 1, pp. 95-102, 2005.

[60] A. Masood, N. Iqbal, and N. A. Khan, "Role of ethylene in alleviation of cadmium-induced photosynthetic capacity inhibition by sulphur in mustard," Plant, Cell \& Environment, vol. 35, no. 3, pp. 524-533, 2012.

[61] A. Vassilev, I. Iordanov, E. Chakalova, and V. Kerin, "Effect of cadmium stress on growth and photosynthesis of young barley (H. vulgare L.) plants, Structural and functional changes in the photosynthetic apparatus," Bulgarian Journal of Plant Physiology, vol. 21, pp. 12-21, 1995. 


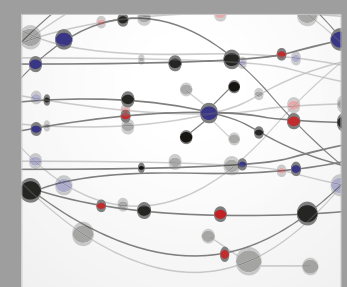

The Scientific World Journal
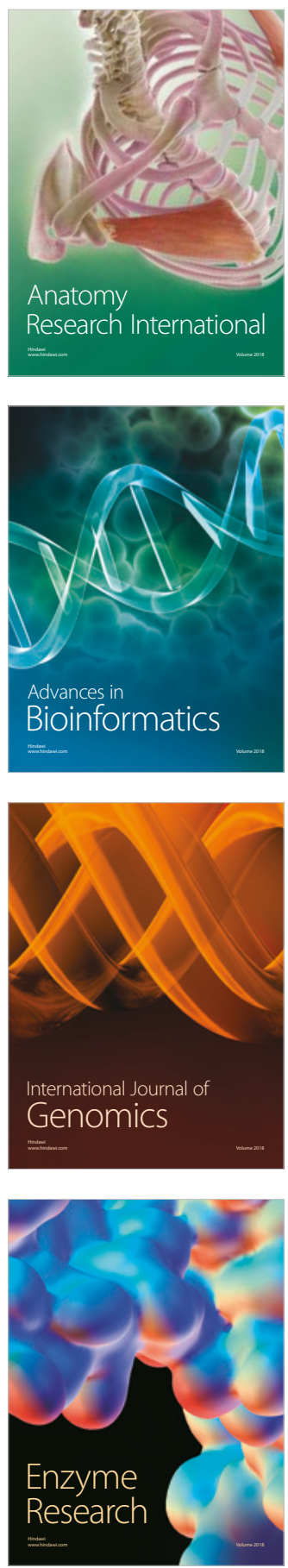
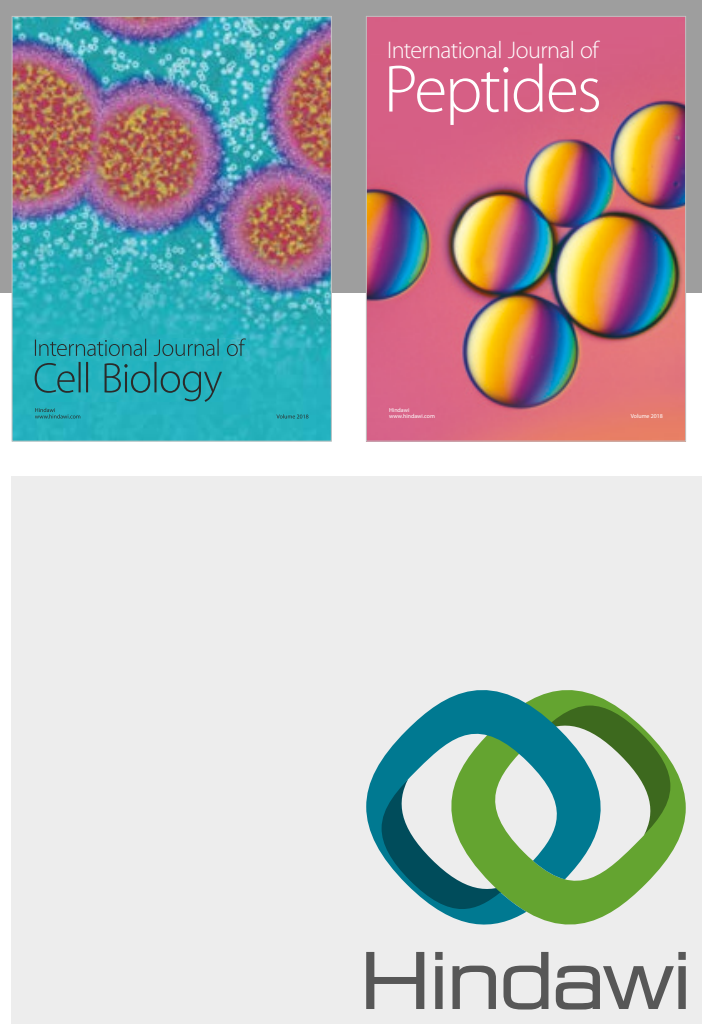

Submit your manuscripts at

www.hindawi.com
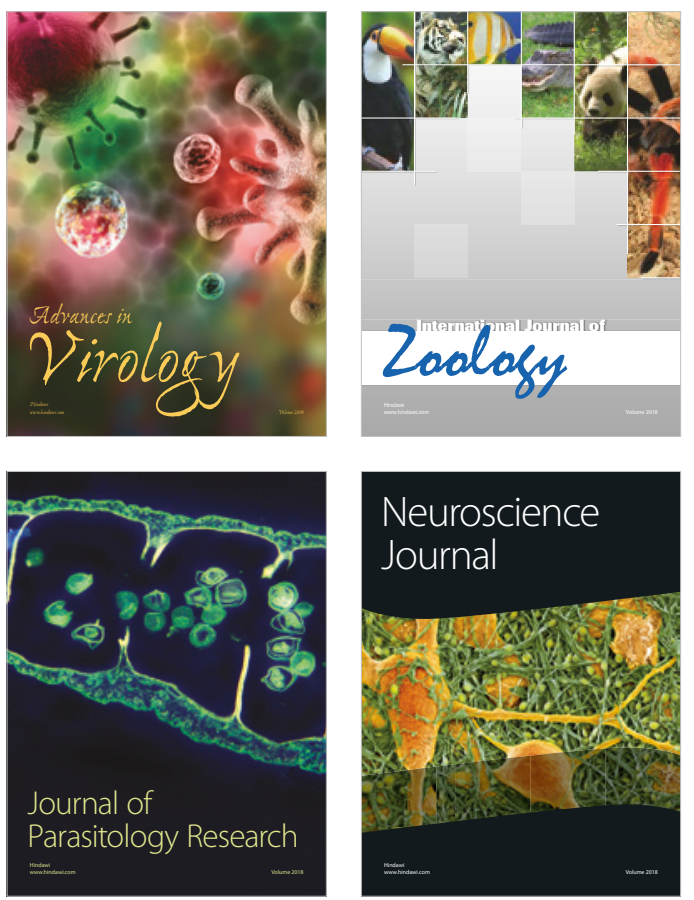
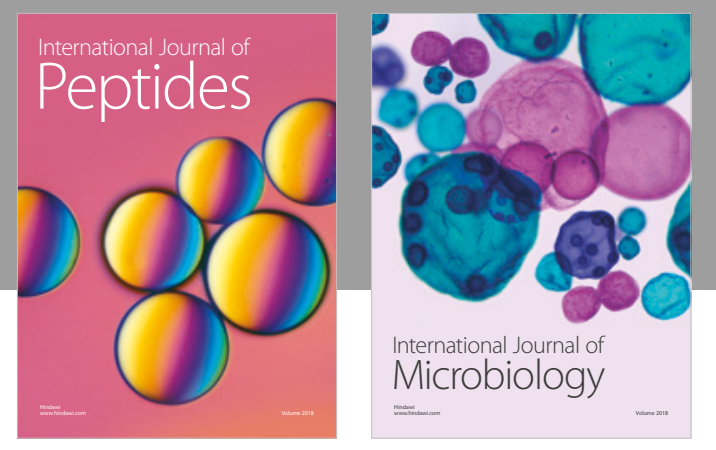

nternational Journal of Microbiology
Journal of
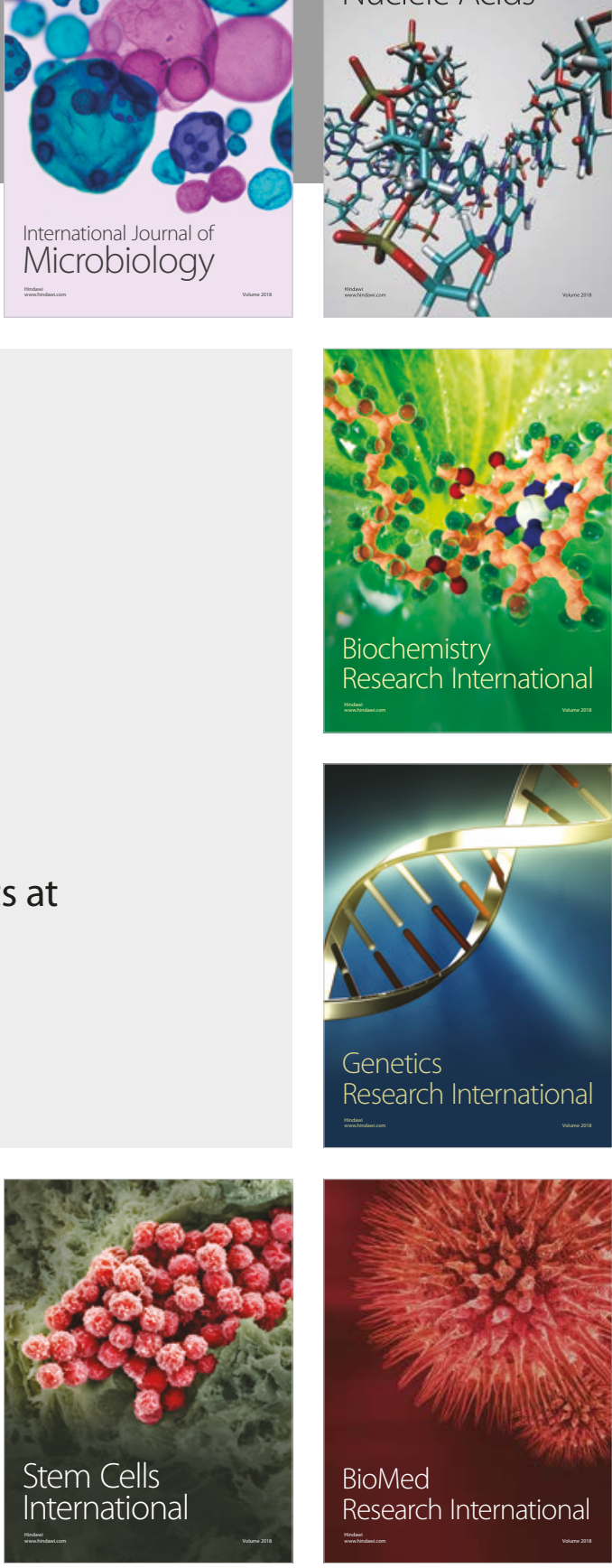
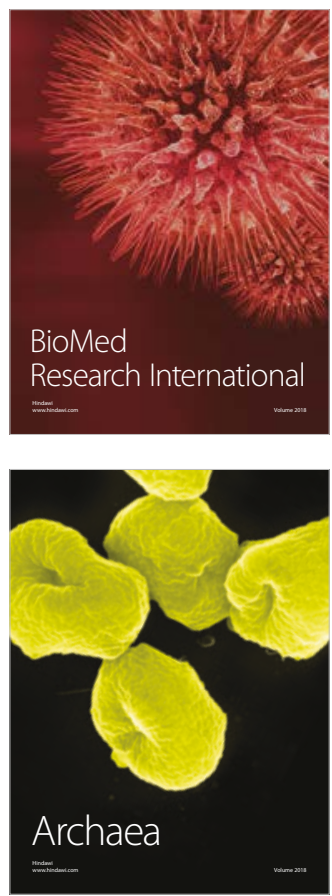